\title{
Effects of a single transdermal administration of flunixin meglumine in early postpartum Holstein Friesian dairy cows: Part 1. Inflammatory and metabolic markers, uterine health, and indicators of pain
}

\author{
R. Schmitt, ${ }^{1 *} \odot$ L. Pieper, ${ }^{2} \odot$ S. Borchardt, ${ }^{3} \odot$ J. M. Swinkels, ${ }^{4} \odot$ C.-C. Gelfert, ${ }^{5} \odot$ and R. Staufenbiel ${ }^{1} \odot$ \\ ${ }^{1}$ Ruminant and Swine Clinic, Free University of Berlin, Germany 14163 \\ ${ }^{2}$ Department of Farm Animal Surgery, Vetsuisse Faculty, University of Zürich, Switzerland 8057 \\ ${ }^{3}$ Clinic for Animal Reproduction, Free University of Berlin, Germany 14163 \\ ${ }^{4}$ Global Ruminants Business Unit, MSD Animal Health, Boxmeer, the Netherlands 5831 \\ ${ }^{5}$ Intervet GesmbH, MSD Animal Health, Vienna, Austria 1210
}

\section{ABSTRACT}

The objectives of this study were to assess the effects of a single transdermal administration of flunixin meglumine (FM) in early postpartum Holstein Friesian dairy cows on serum concentrations of inflammatory and metabolic markers, uterine health, and indicators of pain. The hypothesis was that the anti-inflammatory, antipyretic, and analgetic effects of the pharmaceutic agent would reduce systemic inflammation, resulting in improved metabolic and inflammatory profile, diminished incidence of metritis, and reduced expression of pain. A total of 500 cows (153 primiparous, 347 multiparous) from 3 different commercial dairy farms in the northeast of Germany were included in a randomized controlled clinical trial. Farms were preselected based on high haptoglobin concentrations in their fresh lactating cows. Cows were excluded if they had experienced dystocia, stillbirth, or twin birth, or if they showed any signs of milk fever, retained fetal membranes, or fever $\left(>40^{\circ} \mathrm{C}\right)$. The cows were treated once with either FM $(3.33 \mathrm{mg} / \mathrm{kg})$ or a placebo as control $(\mathrm{CON})$ through transdermal administration between 24 to 36 $\mathrm{h}$ postpartum (d 2). General health examinations were performed (daily from d 2-8 and additionally on d 15 postpartum), vaginal discharge was assessed using the Metricheck device (d 8 and 15 postpartum) and serum samples were analyzed for inflammatory and metabolic markers (d 2, 4, and 6 postpartum). Effects of treatment, parity, sampling day, and their interactions were evaluated using mixed effects models. Primiparous cows treated with FM showed lower serum haptoglobin concentrations $(0.90 \pm 0.08$ vs. $1.17 \pm 0.07 \mathrm{~g} / \mathrm{L} ; \pm$ standard error of the mean) and higher serum albumin

Received April 1, 2021.

Accepted November 17, 2021

*Corresponding author: ruth.schmitt@fu-berlin.de concentrations $(35.5 \pm 0.31$ vs. $34.8 \pm 0.31 \mathrm{~g} / \mathrm{L})$ on $\mathrm{d}$ 6 postpartum. They also had a lower risk for purulent vaginal discharge with or without a fever compared with CON cows on d 15 postpartum (odds ratio for CON vs. FM: 1.63, 95\% CI: 1.26-2.00), and body temperature was lower throughout the first $15 \mathrm{~d}$ in milk $(39.1 \pm 0.11$ vs. $39.2 \pm 0.11^{\circ} \mathrm{C}$ ). Multiparous cows treated with FM had lower serum $\beta$-hydroxybutyrate concentrations on d 4 postpartum $(0.71 \pm 0.05$ vs. $0.78 \pm 0.05 \mathrm{mmol} / \mathrm{L})$ and $\mathrm{d} 6$ postpartum $(0.74 \pm 0.05$ vs. $0.80 \pm 0.05$ mmol/L). Regardless of parity, FM-treated cows were significantly less likely to abduct their tail from their body (14.3 vs. $23.6 \%)$ and show an arched back (27.9 vs. $39.7 \%$ ) on the day after treatment compared with CON cows. It can be concluded that FM treatment slightly reduced inflammation and diminished the risk for metritis in primiparous cows, improved metabolic profile in multiparous cows, and reduced expressions of pain in all cows.

Key words: inflammation, transition, dairy cow, flunixin meglumine, metritis

\section{INTRODUCTION}

Systemic inflammation in the periparturient dairy cow has been the focus of much research in recent years (Sordillo and Raphael, 2013; Bradford et al., 2015; Bradford and Swartz, 2020). A physiological role of inflammation around parturition has been described concomitant with the expulsion of fetal membranes and uterine involution (Sheldon et al., 2019). An excessive inflammatory response, however, has a negative effect on nutrient availability (Bradford and Swartz, 2020). This has been associated with a higher incidence of metabolic and infectious diseases in early postpartum dairy cows (Sordillo et al., 2009).

Excessive systemic inflammation can already be detected in apparently clinically healthy cows (Humblet et al., 2006; Bionaz et al., 2007; Trevisi et al., 2011; 
Bossaert et al., 2012). Complex interrelationships between immune tolerance, resistance, and resilience of the individual on the one hand, and environmental factors on the other hand are highly likely to determine the degree of systemic inflammation (Sheldon et al., 2019). Systemic inflammation has been associated with a decrease in DMI (Pascottini et al., 2019), negative energy balance, lipid mobilization, and ketone body formation (Guzelbektes et al., 2010; El-Deeb and El-Bahr, 2017), uterine disease (Huzzey et al., 2009; Brodzki et al., 2015; Barragan et al., 2018b), and social stress (Giannetto et al., 2011; Chebel et al., 2016). Primiparous cows seem to have a higher risk for excessive systemic inflammation postpartum (Schneider et al., 2013; Mainau et al., 2014; Pohl et al., 2015) and are more susceptible for acute puerperal metritis as well (Venjakob et al., 2019).

Excessive systemic inflammation around parturition can impair whole lactation productivity, health, and reproductive performance of dairy cows (Krause et al., 2014; Huzzey et al., 2015; Nightingale et al., 2015). Therefore, several approaches to modulate postpartum immune response have been tested to mitigate the negative effects of excessive systemic inflammation postpartum. Among others, treatment of transition dairy cows with nonsteroidal anti-inflammatory drugs (NSAID) has been evaluated in several studies.

Acetylsalicylic acid (ASA) treatment early in the postpartum period resulted in inconclusive effects regarding inflammatory markers in blood and health events. Bertoni et al. (2004) and Barragan et al. (2018a) reported a reduction in the acute-phase proteins (APP) haptoglobin (HP) and ceruloplasmin, and higher concentrations of total protein, albumin, and retinol-binding protein in treated cows. Barragan et al. (2020b) and Montgomery et al. (2019) did not find any effects of treatment on HP concentration, but Barragan et al. (2020b) found lower concentrations of BHB in treated cows. On the contrary, Carpenter et al. (2016) observed increased HP concentrations in ASA-treated animals compared with controls. Two studies reported an increase in metritis incidence in multiparous cows (Bertoni et al., 2004; Farney et al., 2013b).

Meloxicam (MEL) treatment around parturition led to a decreased serum HP and BHB concentration, whereas glucose and IGF-1 were higher in treated cows than in the control group (Pascottini et al., 2020). Contrary to this, Newby et al. (2013a), who treated dairy cows following assisted parturition, and Mainau et al. (2014), who treated apparently healthy cows after calving, did not find any effects of MEL treatment on blood metabolites or health events, but treated heifers were significantly more active during the first $2 \mathrm{~d}$ postpartum (Mainau et al., 2014), which has been associated with a lower risk for metritis before (Barragan et al., 2018b).

Meier et al. (2014) reported slightly lower serum BHB concentrations in cows treated with carprofen (CAR), whereas Giammarco et al. (2018) did not find any effects of CAR on metabolic and inflammatory markers in blood.

Ketoprofen (KET) treatment reduced serum concentrations of HP, BHB, nonesterified fatty acids (NEFA) and tumor-necrosis-factor (TNF)- $\alpha$ in high-yielding dairy cows (Kovacevic et al., 2018). Gladden et al. (2018), however, did not find any significant effects of KET treatment early after parturition. Richards et al. (2009) reported a lower incidence of retained fetal membranes in cows treated with KET immediately after parturition.

Giammarco et al. (2018), who treated cows within 12 $\mathrm{h}$ postpartum with flunixin meglumine (FM), reported a lower incidence of retained fetal membranes in treated cows compared with control, whereas Newby et al. (2017), Shwartz et al. (2009), and Waelchli et al. (1999) found an increased risk for cows to experience stillbirth and retain fetal membranes when treated either before or immediately after parturition, respectively.

Overall, anti-inflammatory medication of transition dairy cows seems promising, but comparison among studies is complicated as they differ in their study design, NSAID, timing of treatment, and dosing regimen. Hence, there is a lack of consensus when it comes to selecting the most appropriate NSAID and treatment protocol.

Flunixin meglumine is a potent NSAID, and the transdermal administration route is more comfortable for the animal compared with injections. However, possible adverse effects, as aforementioned (Waelchli et al., 1999; Shwartz et al., 2009; Newby et al., 2017), need to be prevented, presumably by choosing the right time frame and animal inclusion criteria for the administration.

The objectives of this study were to evaluate the effects of a single transdermal administration of FM in dairy cows between 24 to $36 \mathrm{~h}$ after parturition on serum concentrations of inflammatory and metabolic markers, uterine health and indicators of pain in early lactation. We hypothesized that treatment with FM leads to a reduced inflammatory response and therefore, results in an improved inflammatory and metabolic profile, reduced incidence of puerperal metritis and decreased expression of pain.

\section{MATERIALS AND METHODS}

The experimental procedures reported herein were conducted with the approval of the Institutional Ani- 
mal Care and Use Committee of the Free University of Berlin in cooperation with the Federal State Office of Occupational Safety, Consumer Protection and Health (animal care protocol number: 2347-10-2018).

\section{Animals and Farms}

A total of 500 lactating Holstein Friesian cows ( $\mathrm{n}=$ 153 primiparous, $\mathrm{n}=347$ multiparous) from 3 large commercial dairy farms were enrolled in the study from November 2018 to November 2019. Farms with excessive postpartum inflammation were preselected from a preliminary trial (Schmitt et al., 2021b), including a farm-level screening for serum HP concentration in fresh lactating cows. Farm inclusion criteria for the present study were herd size above 1,000 milking cows, location in the northeast of Germany, freestall housing, and increased mean serum HP concentration in 10 fresh lactating cows (above $0.6 \mathrm{~g} / \mathrm{L}$; Humblet et al., 2006; Huzzey et al., 2009; Chan et al., 2010; Montgomery et al., 2019) discovered in the abovementioned preliminary trial. Farm size ranged from 1,276 to 2,630 cows in total, the average 305-d milk yield ranged from 9,494 to $10,228 \mathrm{~kg}$. During the study period, the average daily milk yield per cow was $32.4,36.4$, and 33.3 $\mathrm{kg}$ with $4.15,3.87$, and $3.88 \%$ fat and $3.56,3.40$, and $3.37 \%$ protein for farms 1,2 , and 3 , respectively. Cows on all 3 farms were fed a TMR based on grass silage, corn silage, alfalfa silage (farm 1, early postpartum ration), alfalfa hay (farm 3, early postpartum ration), wheat straw, different concentrates, supplements, and a mineral mix twice daily (Supplemental Tables S1 and S2; https://doi.org/10.5281/zenodo.5595243; Schmitt et al., 2021a). All farms housed their prepartum cows in loose bedded pack pens and provided a minimum of $8 \mathrm{~m}^{2}$ lying space per cow (range: $8-18 \mathrm{~m}^{2}$ ). On farm 1 , fresh cows were kept in a one-row freestall barn with cubicles equipped with rubber mats and slatted floors. Up to $5 \mathrm{~d}$ postpartum (p.p.), multiparous cows were additionally offered an area with deep straw bedding. On farm 2, fresh cows were housed in a 3-row freestall barn with cubicles with recycled manure solids as bedding. On farm 3, fresh cows were kept in a group pen with deep straw bedding until $10 \mathrm{~d}$ p.p., when they were allocated to a 4-row freestall barn with cubicles equipped with rubber mats and slatted floors. Maximum stocking density in the early postpartum period was 1:1 for all farms, whereas average stocking density ranged from 1:1.2 for both farm 1 and farm 2, and 1:1.8 for farm 3, respectively. On farm 1, heifers and cows were grouped separately throughout the transition period and early lactation and were not commingled until confirmed pregnancy. On farm 2 and 3, heifers and cows were grouped together throughout the transi- tion period and early lactation. On all 3 farms, fresh cows were milked twice daily in either a herringbone (farm 1 and 2) or side-by-side (farm 3) milking parlor. Calving ease was recorded by trained farm personnel on a 4 -point score $(1=$ no assistance, $2=$ assistance by one person without the use of mechanical force, $3=$ mechanical extraction of the calf with an obstetric calfpuller, $4=$ cesarean section or fetotomy) as described by Schuenemann et al. (2011).

\section{Sample Size Calculation}

Assuming a power of $80 \%$, a confidence level of $95 \%$, a 2-tailed test, and a minimum difference of $1.31 \mathrm{~g} / \mathrm{L}$ in serum HP concentration on d 6 p.p. (i.e., $0.31 \pm$ $0.08 \mathrm{~g} / \mathrm{L}$ vs. $1.62 \pm 0.47 \mathrm{~g} / \mathrm{L}$; Huzzey et al., 2009) between cows treated with FM and cows that remained untreated, a minimum sample size of 70 was calculated using Stata/IC 13.1 (StataCorp.). Due to the use of 3 different herds, the sample size was increased as suggested by Dohoo et al. (2009), using the following formula: $\mathrm{n}^{\prime}=\mathrm{n}(1+\mathrm{r}(\mathrm{m}-1))$, where $\mathrm{n}^{\prime}$ is the new sample size, $\mathrm{n}$ is the sample size calculated for a simple 2 -sample $t$-test, $\mathrm{r}$ is the intracluster correlation coefficient, and $\mathrm{m}$ is the number of animals sampled per farm. Using an intracluster correlation coefficient of $\mathrm{r}$ $=0.04$ and $\mathrm{m}=150$ cows per farm, a total of 488 cows were considered necessary to successfully complete this study. We aimed to enroll 500 cows (250 cows per treatment) as we expected a loss of approximately $2 \%$ of cows or samples through severe disease, sudden death, slaughter, euthanasia or insufficient sample quality and laboratory problems, respectively.

\section{Treatment Allocation}

Cows that had a eutocia (score 1 and 2 ) with a singleton 24 to $36 \mathrm{~h}$ before first examination were regarded as eligible for enrollment. The first clinical examination was performed immediately before treatment on d 2 p.p. Cows were excluded if they had rectal body temperature (RBT) above $40^{\circ} \mathrm{C}$ or any clinical signs of retained fetal membranes (RFM) or milk fever (MF). Clinical MF was defined according to Kelton et al. (1998) as a cow that showed typical signs of hypocalcemia (e.g., weakness or weight shifting, muscle tremors, sternal or lateral recumbency, decreased gastrointestinal activity, rapid heart rate, weak pulse, decreased rectal temperature) within $72 \mathrm{~h}$ after parturition. A cow was considered to have RFM when the fetal membranes were visible at the vulva more than $24 \mathrm{~h}$ after the first observation of the cow following parturition (Kelton et al., 1998). 
A study-independent person covered the bottle labels of both placebo [Allura Red AC (E129), $0.2 \mathrm{mg} / \mathrm{mL}$ in PBS] and Finadyne Transdermal [FM, $83 \mathrm{mg} / \mathrm{mL}$; levomenthol, $50 \mathrm{mg} / \mathrm{mL}$; Allura Red AC (E129), $0.2 \mathrm{mg} /$ mL; MSD Animal Health] with nontransparent tape and consecutively numbered them in alternating order. Cows were blocked by parity. Within primiparous cows (i.e., parity 1) and multiparous cows (i.e., parity $\geq 2$ ) treatment was alternated with even and uneven bottle numbers, respectively. Hence, every second cow received FM treatment at a dose of $3.33 \mathrm{mg} / \mathrm{kg}$ of estimated BW (FM group, $\mathrm{n}=250$ ), whereas the other cows received a placebo (CON group, $\mathrm{n}=250$ ). Treatment was blinded for farm personnel and the veterinarian conducting the study (R. Schmitt), as well as for all co-authors involved in statistical analyses.

\section{Clinical Examinations and Sampling}

All clinical examinations and samplings described in this part were conducted by the same person. Clinical health examinations were performed daily up to $d 8$ p.p. and repeated once on d 15 p.p. Rectal body temperature was measured on all examination days using a digital thermometer (VT 1831 Veterinary Thermometer, Klifovet). Body condition score (Edmonson et al., 1989) was determined on $\mathrm{d} 2$ and 15 p.p. Rumen fill score (RF; $1-5$ scale according to Zaaijer and Noordhuizen, 2003) and locomotion score (LS) (1-5 scale according to Sprecher et al., 1997) were recorded on d 2, 4, 6, 8, and 15 p.p. Tail position (score $0=$ tail relaxed, score $1=$ tail abducted) and back arching (score $0=$ back straight, score $1=$ back arched) were recorded on d 2, 3, 4, 6, 8, and 15 p.p. Additionally, the character of vaginal discharge was assessed using the Metricheck (MC) device (Simcro Tech Ltd.; McDougall et al., 2007) on d 8 and 15 p.p. Vaginal discharge was scored on a 0 to 3 scale (score $0=$ clear, mucoid discharge; score $1=$ mucopurulent discharge with $<50 \%$ of pus; score $2=$ mucopurulent discharge with $>50 \%$ of pus; score 3 = brownish-reddish, watery, foul-smelling discharge) as described previously (Sheldon and Dobson, 2004; Sheldon et al., 2006; McDougall et al., 2007; Senosy et al., 2012; Lambertz et al., 2014). Based on MC score and RBT on d 8 and 15 p.p., respectively, 4 uterine health categories (UHC) were defined (score $1=\mathrm{MC}$ score $\leq 1$ and $\mathrm{RBT}<39.5^{\circ} \mathrm{C}$; score $2=$ MC score $\leq 1$ and $\mathrm{RBT} \geq 39.5^{\circ} \mathrm{C}$; score $3=\mathrm{MC}$ score $\geq 2$ and $\mathrm{RBT}$ $<39.5^{\circ} \mathrm{C}$; score $4=\mathrm{MC}$ score $\geq 2$ and $\mathrm{RBT} \geq 39.5^{\circ} \mathrm{C}$ ).

Blood samples were obtained on d 2 (immediately before treatment), d 4, and d 6 p.p. by coccygeal venipuncture using an open blood collection system with a $1.8 \times 43-\mathrm{mm}$ Strauß-cannula and a plain tube $(12 \mathrm{~mL})$ for serum collection (Sarstedt Ag \& Co. KG). Samples were allowed to clot for at least one hour at room temperature and subsequently centrifuged for $15 \mathrm{~min}$ at $3,500 \times g$ and a temperature of $20^{\circ} \mathrm{C}$. Serum aliquots were pipetted into plain tubes and stored at $-24^{\circ} \mathrm{C}$ for up to 2 mo before analysis.

\section{Serum Analyses}

Serum was analyzed for HP by a hemoglobin binding method (Owen et al., 1960, Makimura and Suzuki, 1982) using Cobas 8000 C 701 chemical autoanalyzer (Roche Diagnostics) with phase Haptoglobin Assay Cat. No. TP-801 (Tridelta Development) in a commercial laboratory (Laboklin $\mathrm{GmbH} \& \mathrm{Co}$. KG). The lower detection limit of the HP assay was $0.005 \mathrm{~g} / \mathrm{L}$, the intra- and interassay coefficient of variation $(\mathbf{C V})$ ranged from 0.4 to $2.0 \%$ and 3.7 to $6.8 \%$, respectively. Albumin (Alb), total protein (TP), BHB, NEFA, Ca, and phosphate were determined using a Cobas Mira Plus CC chemical autoanalyzer (Roche Diagnostics). The mean intra-assay $\mathrm{CV}$ was $0.5,1.8,3.2,3.9,1.5$, and $2.0 \%$ for Alb, TP, BHB, NEFA, Ca, and phosphate, respectively. The mean interassay $\mathrm{CV}$ was $1.1,2.2,6.5$, 8.4, 4.3, and $3.2 \%$ for Alb, TP, BHB, NEFA, Ca, and phosphate, respectively.

\section{Diagnosis of Health Events}

Throughout the first 10 DIM cows were assessed daily for health status by trained farm personnel on all 3 farms. Health examinations included daily assessment of changes in milk yield, RBT, and visual assessment of vaginal discharge, signs of dehydration (e.g., sunken eyes), and depression (e.g., general appearance, decreased appetite, poor rumen fill). Cows with abnormal findings were examined more thoroughly including rectal palpation, abdominal and cardiovascular auscultation, and blood (farm 1) or urine (farm 2 and 3) testing for BHB and acetoacetate concentration, respectively.

Acute puerperal metritis was diagnosed when a cow had a fever $\left(\geq 39.5^{\circ} \mathrm{C}\right)$ and reddish-brownish, watery, foul-smelling vaginal discharge (Sheldon et al., 2006). A cow was considered to have clinical metritis in case foul-smelling vaginal discharge was present but RBT was normal (Sheldon et al., 2006).

Cases of clinical ketosis were defined as cows that had a decreased appetite concomitantly with elevated blood BHB concentration $(\geq 1.2 \mathrm{mmol} / \mathrm{L})$ in the absence of another primary disease (Kelton et al., 1998). Subclinical ketosis was defined as a cow that had blood BHB concentration $\geq 1.2 \mathrm{mmol} / \mathrm{L}$ (farm 1 ) or increased urine acetoacetate concentration $(>50 \mathrm{mg} / \mathrm{dL}$; farm 2 and 3) but did not show signs of disease such as anorexia and reduced milk yield. A cow was considered having 
a displaced abomasum when she had a decreased appetite accompanied by an audible, characteristic ping sound produced by percussion of the abdominal wall (Kelton et al., 1998). Clinical cases of mastitis were defined as cows that showed unusual milk consistency from one or more udder quarters, as determined by trained milking personnel during the milking routine, that might or might not have been accompanied by signs of inflammation of the udder tissue (e.g., heat, swelling, redness; Kelton et al., 1998).

Trained farm personnel or the farm's veterinarians treated all cases of clinical disease according to common protocols in accordance with the local veterinarian. Within the first 15 DIM, treatment with an NSAID or an antibiotic (AB) alone or combined due to clinical signs of disease that required medication (e.g., high fever, sunken eyes, dullness, anorexia, poor rumen fill, fetid discharge, or severe mastitis) was considered a supportive therapy, which was documented, but the cows were not excluded from subsequent data collection.

\section{Statistical Data Analyses}

Clinical cow data assessed during the trial were collected in Microsoft Excel (Microsoft Office 2013; Microsoft Deutschland Ltd.). Medical data collected by farm personnel were transferred from the herd management software HERDEplus (dsp-Agrosoft Ltd.) to Microsoft Excel. Statistical analyses were performed using SPSS for Windows (Version 26.0; SPSS Inc.).

Comparison of Initial Data Distribution Between Treatment Groups (GENLINMIXED Model). To assess possible differences between treatment groups at the time of enrollment (i.e, d 2 p.p.), the GENLINMIXED procedure was used. The following parameters were tested: time from calving to treatment, lactation number, RBT, BCS, all serum metabolites, RF, LS, tail position and back arching. A generalized linear mixed model, a multinomial logistic regression model, and a binary logistic regression model were built for continuous, ordinal, and binary variables, respectively. Cow was the experimental unit, farm was considered a random effect, and treatment, parity and the interaction of treatment by parity were forced into the model as fixed effects (for lactation number, the parity variable was removed from the model).

Comparison of the Number of Supportive Therapy Cases Between Treatment Groups. The number of cows receiving supportive therapy in the course of the study period was compared between treatment groups using a chi-squared test.

Evaluation of the Treatment Effect on Continuous Variables (GENLINMIXED Model). To evaluate the treatment effect on continuous variables, a generalized linear mixed model was built using the GENLINMIXED procedure as already outlined above. Here, the outcome variable was HP, NEFA, BHB, TP, Alb, Ca, phosphate, RBT, and BCS loss, respectively. Except for BCS loss (not repeated), the model accounted for both the cluster effect of cows within herd and repeated measurements (day) with a first-order autoregressive covariance structure. Fixed effects of the initial model included sampling time (blood sample on d 4 and 6 p.p.), treatment (CON vs. FM), and parity (primiparous vs. multiparous) and were forced into the model. We tested all biological plausible 2-way interactions. Blood metabolite concentration and RBT on $\mathrm{d}$ 2 p.p. were included as covariates. For BCS loss, both the time variable and covariate were removed from the model.

During the model building process, all variables were tested for normality and homoscedasticity of residuals using graphical methods (histograms, Q-Q-Plots, and scatterplots) and Kolmogorov-Smirnov statistic, respectively. Variables (HP, NEFA, BHB, TP, Alb, Ca, phosphate, RBT, and BCS loss) were not normally distributed according to Kolmogorov-Smirnov test. Therefore, data were $\log _{10}$-transformed and Akaike's information criterion was used to determine if model fit was improved.

Evaluation of the Treatment Effect on Ordinal Variables (Ordinal Regression Analysis). An ordinal regression analysis, including farm as a random effect, parity as fixed effect, and d 2 p.p. as a covariate was conducted to determine effects of the treatment on MC score, UHC, RF, and LS, respectively. The ordinal regression analysis was performed for each examination day separately. In case a significant effect of the treatment was found, the estimated cell probability values for each of the respective variable's categories were compared between treatment groups using the MannWhitney-U-Test.

Evaluation of the Treatment Effect on Binary Variables (GENLINMIXED Model). For both tail position and back arching, a binary logistic regression was performed using the GENLINMIXED procedure as described above. Chi-squared test was used to test for differences in the percentage of cows within treatment that showed an arched back or abduction of their tail on a specific day.

Influence of Parity. Whenever parity had a significant influence or a significant treatment by parity interaction was found, separate models were calculated for primiparous and multiparous cows, respectively. Regardless of the significance level, the treatment effect was forced to remain in the model.

Data Presentation and Level of Significance. Data are presented as least squares means \pm standard 
error of the mean (SEM) unless otherwise indicated. Simple comparisons of continuous variables between parities throughout the study period (including d 2-7 and d 15 p.p.) are presented as arithmetic means \pm SEM and were tested for significance using ANOVA.

Effects were considered significant if $P<0.05$ and tendencies were declared at $0.05 \leq P \leq 0.10$.

\section{RESULTS}

A total of 500 cows (153 primiparous, 347 multiparous) were enrolled. Three multiparous cows died from acute metabolic disorders within the first 15 DIM (CON $=1, \mathrm{FM}=2$, respectively). Within the first 15 DIM, a total of 30 versus 24 cows were supportively treated with NSAID in the CON and FM group, respectively $(P=0.39)$. Supportive AB treatment was performed in $24 \mathrm{CON}$ vs. $20 \mathrm{FM}$ cows, respectively $(P=0.53)$. Combined therapy with NSAID and an AB was performed in $17 \mathrm{CON}$ vs. $15 \mathrm{FM}$ cows, respectively $(P=$ 0.72 ). Rectal body temperature was assessed 8 times in all cows (d 2-8 and d 15). Nineteen out of 4,000 observations were missing. Body condition score and $\mathrm{MC}$ score were assessed 2 times (d 2 and 15, and $\mathrm{d} 8$ and 15 , respectively). Ten out of 1,000 observations were missing. Rumen fill and LS were assessed 5 times (d 2, $4,6,8$, and 15). Eighteen and 36 out of 2,500 observations were missing, respectively. Tail position and back arching were scored 6 times (d 2, 3, 4, 6, 8, and 15) and could not be assessed in 27 out of 3,000 cases. A total of 3 blood samples were missing from d 6 p.p. due to death of the cow $(\mathrm{n}=2)$, and hemolysis at sampling ( $\mathrm{n}$ $=1$ ), respectively. As a result, $\mathrm{n}=1,497$ blood samples were fully analyzed for all serum metabolites.

At enrollment, the distribution of time from calving to treatment $(\mathrm{h})$, lactation number, clinical, and laboratory parameters was not significantly different between the treatment groups (Supplemental Table S3; https://doi.org/10.5281/zenodo.5595243; Schmitt et al., 2021a). There was a significant treatment by parity interaction for HP and $\mathrm{Alb}(P=0.03)$ and a tendency for an interaction for TP $(P=0.07)$. Significant differences $(P<0.05)$ between parities were found for RBT, $\mathrm{RF}$, back arching, tail position, LS, HP, BHB, TP, Ca and P (Supplemental Table S3).

\section{Rectal Body Temperature, Blood Metabolites, and BCS}

Rectal body temperature was influenced by treatment $(P=0.02)$, time $(P<0.001)$, and parity $(P<0.001)$, and a time by parity interaction $(P<0.01)$ was found (Table 1). Rectal body temperature was significantly lower in primiparous cows treated with FM compared with CON $(P=0.04$; Table 2; Figure 1). For multiparous cows, no treatment effect was observed (Table 2 ; Figure 1). Throughout the study period (including d 2 to 7 and d 15 p.p.), RBT was higher in primiparous cows (overall mean: $39.1 \pm 0.02^{\circ} \mathrm{C}$ ) compared with multiparous cows (overall mean: $38.9 \pm 0.01^{\circ} \mathrm{C} ; P<0.001$ ).

Serum HP concentration was influenced by treatment $(P=0.02)$ and parity $(P<0.001)$, and a treatment by

Table 1. Results of the generalized linear mixed model assessing the effects of the placebo $(\mathrm{CON}, \mathrm{n}=250)$ and flunixin meglumine $(\mathrm{FM}, \mathrm{n}=$ 250) treatment on the serum concentrations of haptoglobin (HP), nonesterified fatty acids (NEFA), BHB, total protein (TP), albumin (Alb), $\mathrm{Ca}$, phosphate, rectal body temperature (RBT), and BCS loss ${ }^{1}$

\begin{tabular}{|c|c|c|c|c|c|c|c|c|c|}
\hline Parameter $^{2}$ & \multicolumn{2}{|c|}{ Treatment $^{3}$} & SEM & \multicolumn{6}{|c|}{$P$-value } \\
\hline $\mathrm{HP}, \mathrm{g} / \mathrm{L}$ & 0.91 & 0.82 & 0.04 & 0.02 & 0.88 & $<0.001$ & 0.82 & 0.02 & 0.57 \\
\hline $\mathrm{BHB}, \mathrm{mmol} / \mathrm{L}$ & 0.74 & 0.74 & 0.05 & 0.70 & 0.15 & 0.07 & 0.43 & 0.07 & 0.41 \\
\hline $\mathrm{TP}, \mathrm{g} / \mathrm{L}$ & 69.6 & 69.2 & 0.41 & 0.17 & $<0.001$ & 0.10 & 0.75 & 0.56 & 0.45 \\
\hline $\mathrm{Alb}, \mathrm{g} / \mathrm{L}$ & 35.4 & 35.8 & 0.24 & 0.02 & 0.15 & $<0.001$ & 0.85 & 0.28 & 0.02 \\
\hline $\mathrm{RBT},{ }^{\circ} \mathrm{C}$ & 39.1 & 39.0 & 0.07 & 0.02 & $<0.001$ & $<0.001$ & 0.96 & 0.16 & $<0.01$ \\
\hline BCS loss ${ }^{4}$ & 0.18 & 0.17 & 0.06 & 0.71 & - & 0.39 & - & 0.76 & - \\
\hline
\end{tabular}

${ }^{1}$ For all serum metabolites and RBT, the initial value on d 2 postpartum (immediately before treatment) was included in the model as covariate and had a highly significant influence $(P<0.001)$. Trt $=$ treatment; $\mathrm{T}=$ time; Par $=$ parity.

${ }^{2}$ Data presented as LSM \pm SEM of all sampling time points (d 4 and 6 postpartum for serum metabolites, d 3, 4, 5, 6, 7, 8, and 15 postpartum for RBT), except for BCS loss.

${ }^{3}$ Treatment consisted of one transdermal administration of Finadyne Transdermal [MSD Animal Health; FM, $83 \mathrm{mg} / \mathrm{mL}$; levomenthol, $50 \mathrm{mg} /$ $\mathrm{mL}$; Allura Red AC (E129), $0.2 \mathrm{mg} / \mathrm{mL}$ ] at a dose of $3.33 \mathrm{mg}$ of flunixin/kg of BW (FM group) or a placebo [Allura Red AC (E129), $0.2 \mathrm{mg} /$ $\mathrm{mL}$ in $\mathrm{PBS}]$ as control (CON group).

${ }^{4} \mathrm{BCS}$ loss was calculated by subtracting the cow's individual BCS on d 15 postpartum from the score on d 2 postpartum; therefore, the time variable was removed from the model for this parameter. Nevertheless, BCS loss was considered a continuous variable, and the GENLINMIXED procedure was applied. 
parity interaction was observed $(P=0.02$; Table 1$)$. Primiparous cows treated with FM had lower serum HP concentrations $(P<0.01$; Table 2$)$, with the greatest difference between treatment groups on d 6 p.p. (Figure $2 \mathrm{~A}$ ). In multiparous cows, however, there was no treatment effect on HP (Table 2; Figure 2B). Regardless of treatment and parity, mean serum HP concentration increased after calving and reached a numerical peak on d 4 p.p. (Figure 2A and B). Primiparous cows had higher serum HP concentrations (overall mean: 0.95 $\pm 0.03 \mathrm{~g} / \mathrm{L}$ ) compared with multiparous cows (overall mean: $0.65 \pm 0.02 \mathrm{~g} / \mathrm{L}$ ) throughout the study period $(P<0.001)$.

Serum Alb concentration was influenced by treatment $(P=0.02)$, and parity $(P<0.001)$ and a time by parity interaction was observed $(P=0.02$; Table 1$)$. Primiparous cows treated with FM had higher Alb concentrations $(P=0.02$; Table 2 , Figure $2 \mathrm{C})$. In primiparous cows, serum Alb concentration decreased steadily from d 2 to $\mathrm{d} 6$ p.p., whereas it tended to increase from d 4 to d 6 p.p. in multiparous cows (Figure $2 \mathrm{C}$ and D). Moreover, primiparous cows had slightly lower serum Alb concentrations (overall mean: $35.7 \pm 0.13 \mathrm{~g} / \mathrm{L}$ ) compared with multiparous cows (overall mean: 35.9 $\pm 0.08 \mathrm{~g} / \mathrm{L})$ throughout the study period $(P=0.16)$.

There was a tendency for both an effect of parity and a treatment by parity interaction on serum BHB con- centration $(P=0.07$; Table 1$)$. Serum BHB concentration was significantly lower in FM-treated multiparous cows compared with CON cows $(P<0.01$; Table 2, Figure 3D). Throughout the study period, serum BHB concentration was higher in multiparous cows (overall mean: $0.75 \pm 0.01$ ) compared with primiparous cows (overall mean: $0.67 \pm 0.02 ; P<0.001$ ). When a cut-off point of $\geq 1.2 \mathrm{mmol} / \mathrm{L}$ was applied, no difference was found between treatment groups $(P=0.308)$.

Neither serum TP, NEFA, Ca, and phosphate concentration, nor BCS loss were affected by FM treatment (Table 1).

\section{Metricheck Score and Uterine Health Category}

The treatment effect on MC score and UHC on $\mathrm{d} 8$ and 15 p.p. is summarized in Table 3 and Figure 4. Primiparous CON cows had 1.52 (95\% CI: $1.11-1.93)$ and 1.63 (95\% CI: 1.26-2.00) times the odds of showing a higher MC score compared with FM cows on d 8 and 15 p.p., respectively $(P=0.04$ and $P=0.01$, respectively, Table 3). For multiparous cows, no difference in $\mathrm{MC}$ score was found.

Regardless of parity, treatment had no effect on UHC on d 8 p.p. $(P=0.41$ for primiparous cows and $P=$ 0.42 for multiparous cows, respectively, Table 3). However, on d 15 p.p., primiparous CON cows had 1.63

Table 2. Results of the separate generalized linear mixed models assessing the effects of the placebo $(\mathrm{CON}, \mathrm{n}=78$ primiparous; $\mathrm{n}=172$ multiparous) and flunixin meglumine ( $\mathrm{FM}, \mathrm{n}=75$ primiparous; $\mathrm{n}=175$ multiparous) treatment on serum metabolites $[$ haptoglobin (HP), nonesterified fatty acids (NEFA), BHB, total protein (TP), albumin (Alb), Ca, phosphate, rectal body temperature (RBT), and BCS loss for primiparous and multiparous cows, respectively] $]^{1}$

\begin{tabular}{|c|c|c|c|c|c|c|c|c|c|c|c|c|}
\hline \multirow{2}{*}{ Parameter $^{2}$} & \multicolumn{6}{|c|}{ Primipara } & \multicolumn{6}{|c|}{ Multipara } \\
\hline & \multicolumn{2}{|c|}{ Treatment $^{3}$} & SEM & \multicolumn{3}{|c|}{$P$-value } & \multicolumn{2}{|c|}{ Treatment $^{3}$} & SEM & \multicolumn{3}{|c|}{$P$-value } \\
\hline $\mathrm{HP}, \mathrm{g} / \mathrm{L}$ & 1.13 & 0.96 & 0.06 & $<0.01$ & 0.73 & 0.11 & 0.72 & 0.72 & 0.07 & 0.99 & 0.10 & 0.53 \\
\hline NEFA, mmol/L & 0.50 & 0.49 & 0.11 & 0.83 & 0.15 & 0.35 & 0.52 & 0.50 & 0.06 & 0.21 & 0.15 & 0.98 \\
\hline $\mathrm{BHB}, \mathrm{mmol} / \mathrm{L}$ & 0.66 & 0.70 & 0.06 & 0.42 & 0.20 & 0.50 & 0.79 & 0.73 & 0.05 & $<0.01$ & 0.20 & 0.91 \\
\hline $\mathrm{Ca}, \mathrm{mmol} / \mathrm{L}$ & 2.12 & 2.11 & 0.04 & 0.74 & $<0.001$ & 0.84 & 2.11 & 2.13 & 0.01 & 0.28 & $<0.001$ & 0.26 \\
\hline Phosphate, mmol/L & 1.72 & 1.75 & 0.04 & 0.34 & $<0.001$ & 0.85 & 1.61 & 1.64 & 0.04 & 0.21 & $<0.001$ & 0.81 \\
\hline $\mathrm{RBT},{ }^{\circ} \mathrm{C}$ & 39.2 & 39.1 & 0.10 & 0.04 & $<0.001$ & 0.41 & 39.0 & 38.9 & 0.06 & 0.56 & $<0.01$ & 0.89 \\
\hline BCS loss ${ }^{4}$ & 0.16 & 0.15 & 0.08 & 0.94 & - & - & 0.20 & 0.18 & 0.05 & 0.57 & - & - \\
\hline
\end{tabular}

${ }^{1}$ For all serum metabolites and RBT, the initial value on $\mathrm{d} 2$ postpartum (immediately before treatment) was included in the model as covariate and had a highly significant influence $(P<0.001)$. Trt $=$ treatment; $\mathrm{T}=$ time.

${ }^{2}$ Data presented as LSM \pm SEM of all sampling time points (d 4 and 6 postpartum for serum metabolites, d 3, 4, 5, 6, 7, 8, and 15 postpartum for RBT), except for BCS loss.

${ }^{3}$ Treatment consisted of one transdermal administration of Finadyne Transdermal [MSD Animal Health; FM, $83 \mathrm{mg} / \mathrm{mL}$; levomenthol, $50 \mathrm{mg} /$ $\mathrm{mL}$; Allura Red AC (E129), $0.2 \mathrm{mg} / \mathrm{mL}$ ] at a dose of $3.33 \mathrm{mg}$ of flunixin/kg of BW (FM group) or a placebo [Allura Red AC (E129), $0.2 \mathrm{mg} /$ $\mathrm{mL}$ in $\mathrm{PBS}$ ] as control (CON group), respectively.

${ }^{4}$ BCS loss was calculated by subtracting the cow's individual BCS on d 15 postpartum from the score on d 2 postpartum; therefore, the time variable was removed from the model for this parameter. Nevertheless, BCS loss was considered a continuous variable, and the GENLINMIXED procedure was applied. 
times the odds of showing a higher UHC compared with FM-treated cows (95\% CI: 1.26-2.00, $P=0.01$, Table 3, Figure 4).

\section{Rumen Fill, Locomotion Score}

Treatment had no effect on RF and LS (Table 3).

\section{Indicators of Pain}

Irrespective of parity, treatment with FM reduced the risk for cows to show either an arched back $(P<0.01)$ or an abducted tail $(P=0.02)$ on d 3 p.p. (Figure $5 \mathrm{~A}$ and $\mathrm{B}$, respectively). This difference was not observed on any other day after the treatment.

\section{DISCUSSION}

This study is the first to assess the effects of a single transdermal administration of FM in Holstein Friesian dairy cows between 24 to 36 h p.p. on serum concentrations of inflammatory and metabolic markers, uterine health, and indicators of pain. Rectal body temperature was lower in FM-treated primiparous cows compared with CON. Treated primipara additionally had a lower risk for purulent vaginal discharge with or without a fever, lower serum HP, and higher serum Alb on d 6 p.p. Multiparous cows treated with FM had slightly lower serum BHB concentrations.

Rectal body temperature was significantly yet only slightly lower in primiparous cows treated with FM compared with CON cows, whereas no difference was detected in multiparous cows. This finding might be primarily attributable to the antipyretic effect of transdermal FM shown in another study (Thesing et al., 2016). However, the effect size in primiparous cows was rather small and it remains unclear why RBT was not affected in multiparous cows. Overall, RBT was higher in primiparous cows compared with multiparous cows, as described before (Wenz et al., 2011; Suthar et al., 2012; Burfeind et al., 2014). This is most likely being accounted for by an increased stress level, risk for calving difficulties, susceptibility for uterine disease, and a different peripartum nutrient metabolism in primiparous cows compared with multiparous cows (Schneider et al., 2013; Mainau et al., 2014; Pohl et al., 2015; Venjakob et al., 2019). Taking these differences into account, the antipyretic effect of the treatment could have been more pronounced, hence statistically significant, in primiparous cows. However, our finding is contradictory to Shwartz et al. (2009), who applied FM intravenously, first within $5 \mathrm{~h}$ p.p. then daily for the following $3 \mathrm{~d}$. In this study, treated cows were more likely to be febrile $\left(\mathrm{RBT}>39.5^{\circ} \mathrm{C}\right)$, which was accompanied by a reduced DMI. This might be explained by the time of the first treatment, which was immediately after parturition, when the process of fetal membrane expulsion might have been disturbed by FM induced inhibition of the cyclooxygenase (COX) enzymes, leading to a reduced availability of prostaglandins (PG), including $\mathrm{PGF}_{2 \alpha}$ (Beretta et al., 2005). In fact, other studies reported an increased risk for FM-treated cows to show RFM (Waelchli et al., 1999; Shwartz et al., 2009; Newby et al., 2017). This was associated with

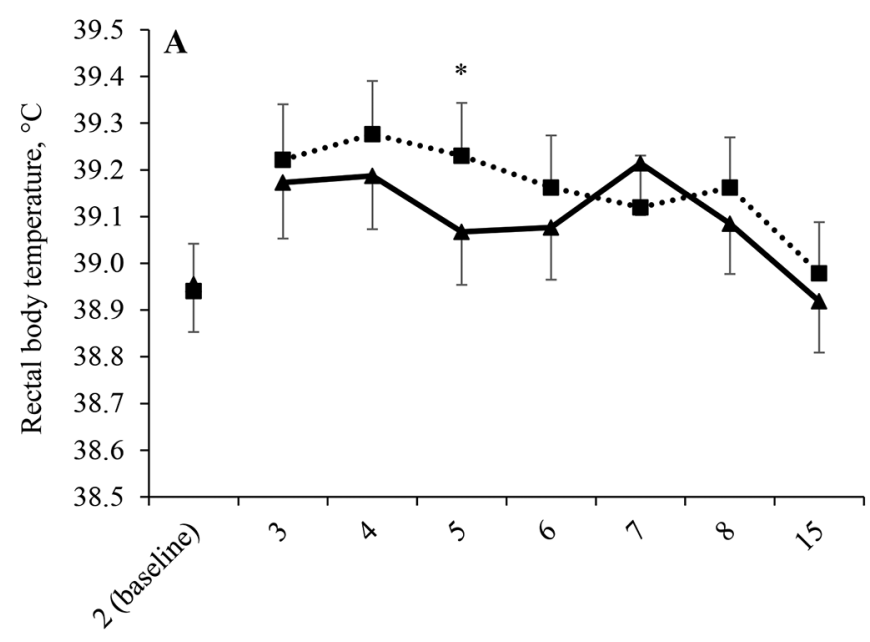

Days in milk

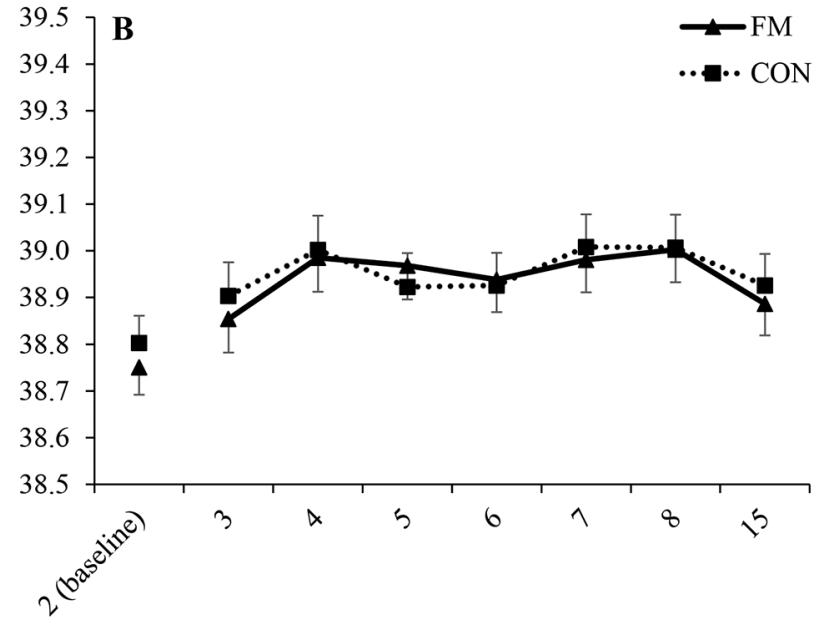

Days in milk

Figure 1. Rectal body temperature of primiparous (A) and multiparous (B) cows treated with a placebo $(\mathrm{CON}, \mathrm{A}: \mathrm{n}=78 ; \mathrm{B}: \mathrm{n}=172)$ or flunixin meglumine (FM, A: $\mathrm{n}=75 ; \mathrm{B}: \mathrm{n}=175$ ), respectively. Treatment was performed on $\mathrm{d} 2$ (between 24 and $36 \mathrm{~h}$ postpartum). Rectal body temperature on d 2 , immediately before treatment (baseline value), was included in the model as covariate. $*$ indicates a significant difference between treatment groups within a day (generalized linear mixed model with repeated measurements; $P<0.05$ ). Data are presented as mean \pm SE. 

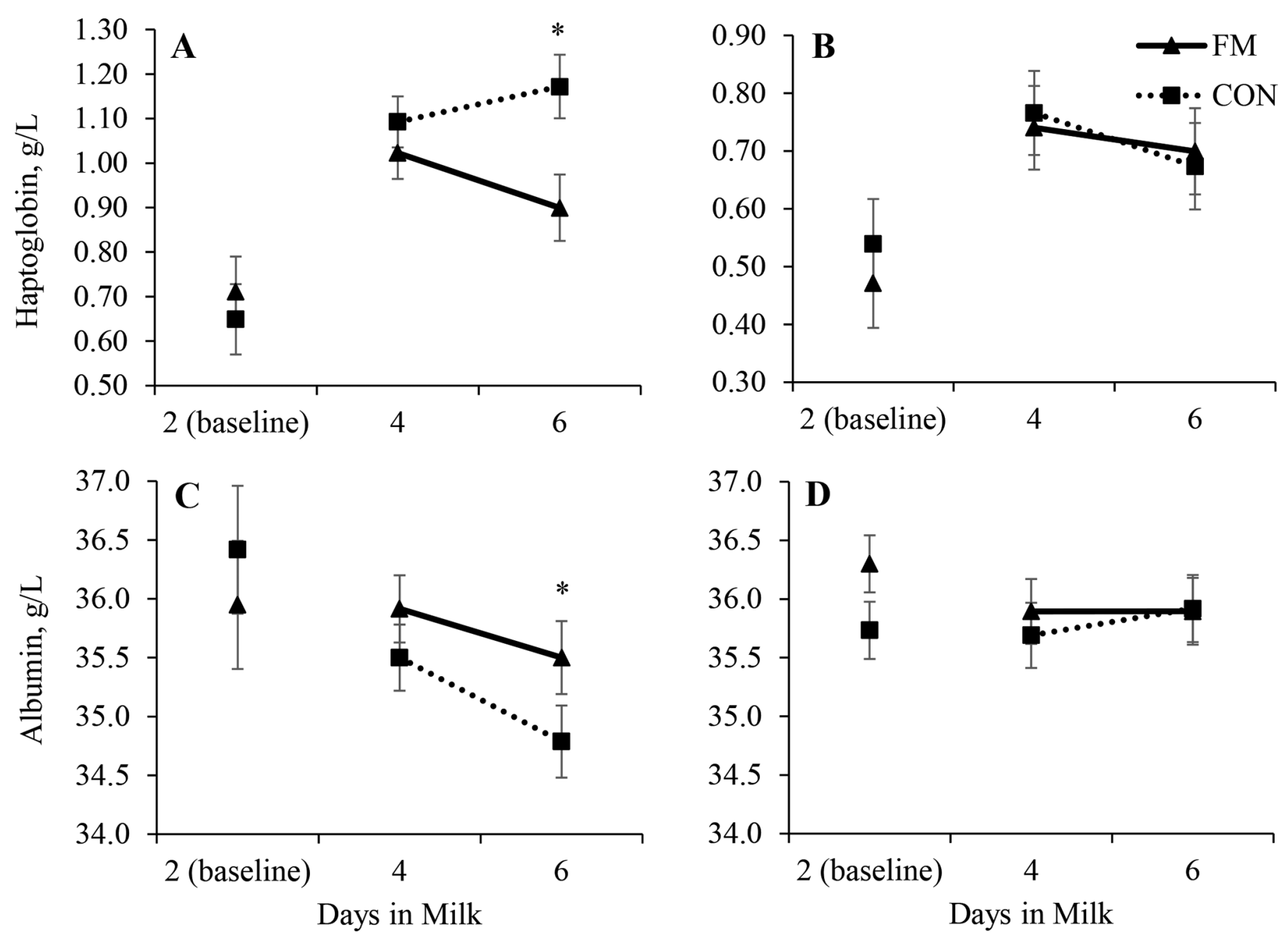

Figure 2. Serum concentrations of haptoglobin and albumin in primiparous (A, C; n = 153) and multiparous cows (B, D; $\mathrm{n}=347)$, respectively. Cows were alternately treated on $\mathrm{d} 2(24-36 \mathrm{~h}$ postpartum) with a placebo (CON) or flunixin meglumine (FM), respectively. The metabolite's serum concentration on d 2 , immediately before treatment (baseline value), was included in the respective model as covariate. * indicates a significant difference between treatment groups within a day (generalized linear mixed model with repeated measurements; $P<$ 0.05). Data are presented as mean \pm SEM.

an increase in RBT in one study (Newby et al., 2017). Additionally, cows treated with FM immediately before calving showed an increased risk of stillbirth (Newby et al., 2017), supporting the abovementioned hypothesis that the time of drug administration is crucial when comparing studies. In the present study, only cows with no clinical signs of RFM were treated between 24 to $36 \mathrm{~h}$ p.p. aiming at avoiding negative effects on fetal membrane expulsion. The slight reduction in RBT for primiparous cows reported in this study might hence be attributable not only to the antipyretic effect of FM, but also to the time of administration and the specific selection of eligible cows for the study.

Concomitant with the aforementioned findings regarding RBT, both parity and treatment had a significant effect on serum HP concentration, which was lower in FM-treated primiparous cows compared with primiparous CON cows. Albumin was higher in FMtreated primiparous cows compared with CON cows. Both findings were not observed in multiparous cows. This coincides partly with previous studies, where treatment of early postpartum dairy cows with ASA (Bertoni et al., 2004; Barragan et al., 2018a, 2020a), KET (Kovacevic et al., 2018), and MEL (Pascottini et al., 2020) resulted in decreased serum HP concentrations, respectively. However, Pascottini et al. (2020) did not observe differences in serum Alb concentration, and other authors reported no effect of treatment with either ASA (Montgomery et al., 2019; Barragan et al., 2020b, 2021) or MEL (Newby et al., 2013a; Mainau et al., 2014) on serum HP concentration, respectively. Interestingly, Barragan et al. (2020a) reported a signifi- 
cant effect of 4 oral ASA treatments in 12-h intervals after calving on serum HP concentration in multiparous cows only, which is contradictory to the present study. In a previous study, Barragan et al. (2020b) conducted a less-intense treatment protocol (i.e., only 2 oral ASA treatments) and found no effect on serum HP concentration. Haptoglobin is a liver-derived hemoglobin scavenger protein, which is part of the acute-phase response of the innate immune system (Baumann and Gauldie, 1994; Heinrich et al., 1990). Triggered by various possible noxious stimuli, macrophages and other immune cells release interleukins such as IL-1- $\beta$, IL-6, and TNF- $\alpha$, thereby enhancing the production of HP and other positive APP in the liver (Heinrich et al., 1990). This process impairs the synthesis of negative APP, such as Alb, whose serum concentration declines concurrently (Bossaert et al., 2012). Complex humoral relationships between different COX-derived PG on the one hand and monocyte-derived IL on the other (Hinson et al., 1996; Ek et al., 2000) might contribute to the variable and in parts antithetic results of the abovementioned studies assessing the effects of NSAID on HP and Alb in early postpartum dairy cows. Additionally, different NSAID vary in their mode of action regarding COX-inhibition, which further explains differences between studies in this field. For example, ASA, FM and
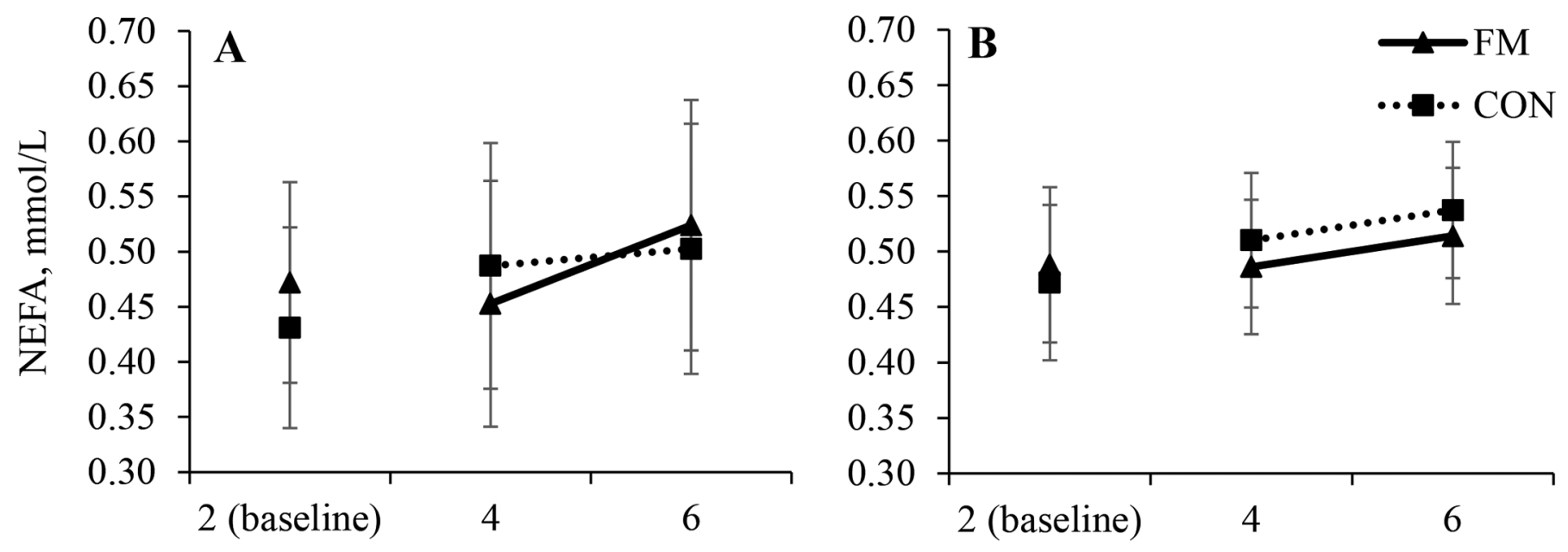

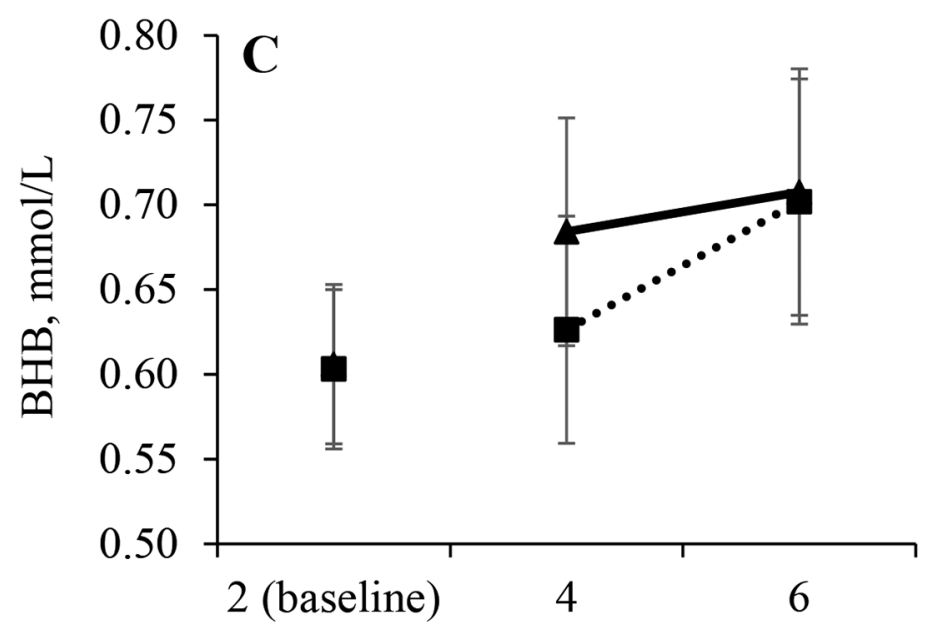

Days in milk

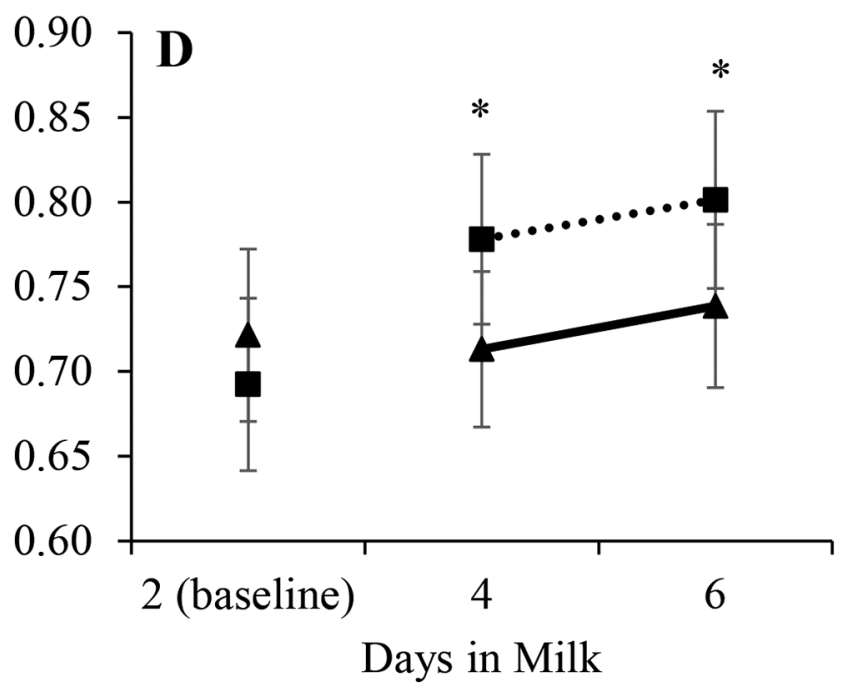

Figure 3. Serum concentrations of nonesterified fatty acids (NEFA) and BHB in primiparous (A, C; $\mathrm{n}=153)$ and multiparous cows $(\mathrm{B}, \mathrm{D} ; \mathrm{n}$ $=347)$, respectively. Cows were alternately treated on d 2 (24-36 h postpartum) with a placebo (CON) or flunixin meglumine (FM), respectively. The metabolite's serum concentration on d 2, immediately before treatment (baseline value), was included in the respective model as covariate. * indicates a significant difference between treatment groups within a day (generalized linear mixed model with repeated measurements; $P<$ 0.05). Data are presented as mean \pm SEM. 
KET preferentially inhibit COX-1, a ubiquitous and constitutively expressed COX-isoform, whereas CAR and MEL selectively inhibit COX-2, which is induced in inflammatory conditions (Beretta et al., 2005). Besides, MEL is known to exhibit anti-endotoxin activity (Königsson et al., 2002), and ASA exerts further effects on nuclear transcription factor NF- $\kappa \mathrm{B}$ and influences rumen fermentation and glucose metabolism (Kopp and Ghosh, 1994; Yuan et al., 2001; Farney et al., 2013a). Furthermore, different results regarding serum APP concentration could have been obtained due to different study designs regarding the type of NSAID administration (e.g., oral, intravenous, intramuscular, and transdermal administration), because this strongly influences their pharmacokinetics. Thiry et al. (2017) found decreased plasma PG concentrations in cattle until up to $48 \mathrm{~h}$ after transdermal administration of $\mathrm{FM}$, thereby proving its efficacy in inhibiting the COX enzymes compared with other application routes (e.g., intravenous). Kleinhenz et al. (2016) reported an even longer plasma half-life for transdermal FM compared with intravenous (6.42 vs. $4.99 \mathrm{~h}$ ). Therefore, the FM induced inhibition of the COX enzymes is likely to have caused the observed differences in serum HP and Alb concentration. Primiparous cows are more prone to excessive postpartum inflammation compared with multiparous cows (Schneider et al., 2013; Mainau et al., 2014; Pohl et al., 2015; Barragan et al., 2020a), and inflammation can increase NSAID concentration in concerned tissues due to an increased vascular permeability and the presence of local binding protein compounds (Martinez and Modric, 2010), hence, the anti-inflammatory effect of the treatment might have been more pronounced here. Other conceivable reasons for the discrepancies in effect size between primiparous and multiparous cows might be age-related differences in the pharmacokinetics of transdermal FM. Kleinhenz (2018) observed significantly different pharmacokinetic characteristics of transdermally administered FM in calves of 2 and 8 mo of age, respectively. In

Table 3. Results of the ordinal regression model assessing the effects of the placebo (CON, $\mathrm{n}=78$ primiparous, $\mathrm{n}=172$ multiparous) and flunixin meglumine (FM, $\mathrm{n}=75$ primiparous, $\mathrm{n}=175$ multiparous) treatment on Metricheck (MC) score, uterine health category (UHC), rumen fill (RF) score and locomotion score (LS) for primiparous and multiparous cows, respectively

Effect of treatment ${ }^{1}$ (CON vs. FM)

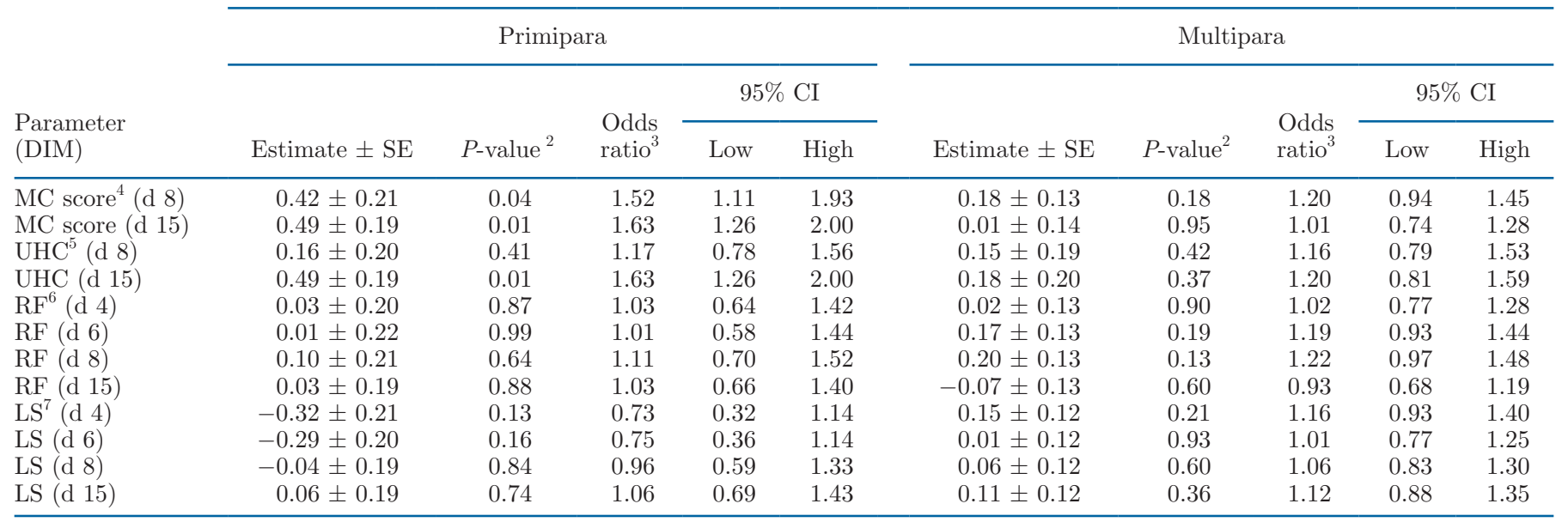

${ }^{1}$ Treatment consisted of one transdermal administration of Finadyne Transdermal (MSD Animal Health; FM, $83 \mathrm{mg} / \mathrm{mL}$; levomenthol, $50 \mathrm{mg} /$ $\mathrm{mL}$; Allura Red AC (E129), $0.2 \mathrm{mg} / \mathrm{mL}$ ) at a dose of $3.33 \mathrm{mg}$ of flunixin/kg of BW (FM group) or a placebo [Allura Red AC (E129), $0.2 \mathrm{mg} /$ $\mathrm{mL}$ in $\mathrm{PBS}]$ as control (CON group), respectively.

${ }^{2}$ Differences between treatment groups for each day were assessed using an ordinal regression analysis. Farm was considered a random effect and treatment was considered a fixed effect. Day 2 was included as a covariate.

${ }^{3}$ In an ordinal regression model with a dichotomous predictor variable (CON vs. FM) and an ordinal dependent variable (e.g., MC score 0-3), the odds ratio describes the risk of finding a higher category of the dependent variable that comes with a one-unit increase in the predictor variable. For example, when FM is defined as reference category within the predictor variable, an odds ratio = 1.5 indicates a 1.5 times increased risk for CON cows to fall into a higher category of the dependent variable compared with FM.

${ }^{4}$ Metricheck score was assessed on a 0 to 3 scale modified according to previous recommendations (Sheldon and Dobson, 2004; Sheldon et al., 2006; McDougall et al., 2007; Senosy et al., 2012; Lambertz et al., 2014).

${ }^{5}$ Four different uterine health categories were defined by MC score and rectal body temperature (RBT; category $1=$ MC score $\leq 1$ and RBT $<39.5^{\circ} \mathrm{C}$; category $2=\mathrm{MC}$ score $\leq 1$ and $\mathrm{RBT} \geq 39.5^{\circ} \mathrm{C}$; category $3=\mathrm{MC}$ score $\geq 2$ and $\mathrm{RBT}<39.5^{\circ} \mathrm{C}$; category $4=\mathrm{MC}$ score $\geq 2$ and RBT $\geq 39.5^{\circ} \mathrm{C}$.

${ }^{6}$ Rumen fill was recorded on a 1 to 5 scale according to Zaaijer and Noordhuizen (2003).

${ }^{7}$ Locomotion score was recorded on a 1 to 5 scale according to Sprecher et al. (1997). 
their study, younger calves had a higher maximum plasma concentration and lower half maximum inhibitory concentration (on plasma $\mathrm{PGE}_{2}$ ) compared with older calves, indicating a higher clinical effectiveness of transdermal FM in younger calves. Skin thickness, increasing with age, but also a higher hepatic clearance of drugs in older animals, were considered possible reasons for these findings. Transferred to the situation of early postpartum cows, a higher liver metabolism concomitant with a higher drug plasma clearance might be found in multiparous cows with higher milk yield, whereas primiparous cows experiencing a higher degree of inflammation in the genital tract might build up higher tissue concentrations of NSAID, which could have contributed to the results of the present study.

In FM-treated multiparous cows, however, the effects of the treatment were reflected by slightly lower serum BHB concentrations, as observed by Barragan et al. (2020b) using ASA. Previously, other authors have reported lower BHB concentrations in NSAID treated cows regardless of parity (Meier et al., 2014; Carpenter et al., 2016; Kovacevic et al., 2018) using CAR, ASA, and KET, respectively. Contradictory to this, Montgomery et al. (2019) reported no effects of ASA treatment on NEFA, BHB, HP, insulin, lactate, adiponectin, and TNF- $\alpha$. Reasons for discrepancies between studies and parities have been outlined above.

Usually, both NEFA (pre- and postpartum) and BHB are used as indicators for negative energy balance and lipomobilization and are associated with increased disease risk, reduced milk production and impaired fertility in subsequent lactation (Ospina et al., 2013). However, serum NEFA concentrations were not affected by FM treatment in the present study, as reported by Carpenter et al. (2016) following MEL and ASA treatment, respectively. It has been shown before that NEFA and BHB values are not necessarily well correlated in the periparturient period (McCarthy et al., 2015), for they are not elevated in the same animal at the same time (Ospina et al., 2013). Ketone body formation is considered a primary consequence of incomplete NEFA oxidation in the hepatocytes following excessive lipid mobilization in periods of negative energy balance (glucose deficiency) at the onset of lactation (LeBlanc,
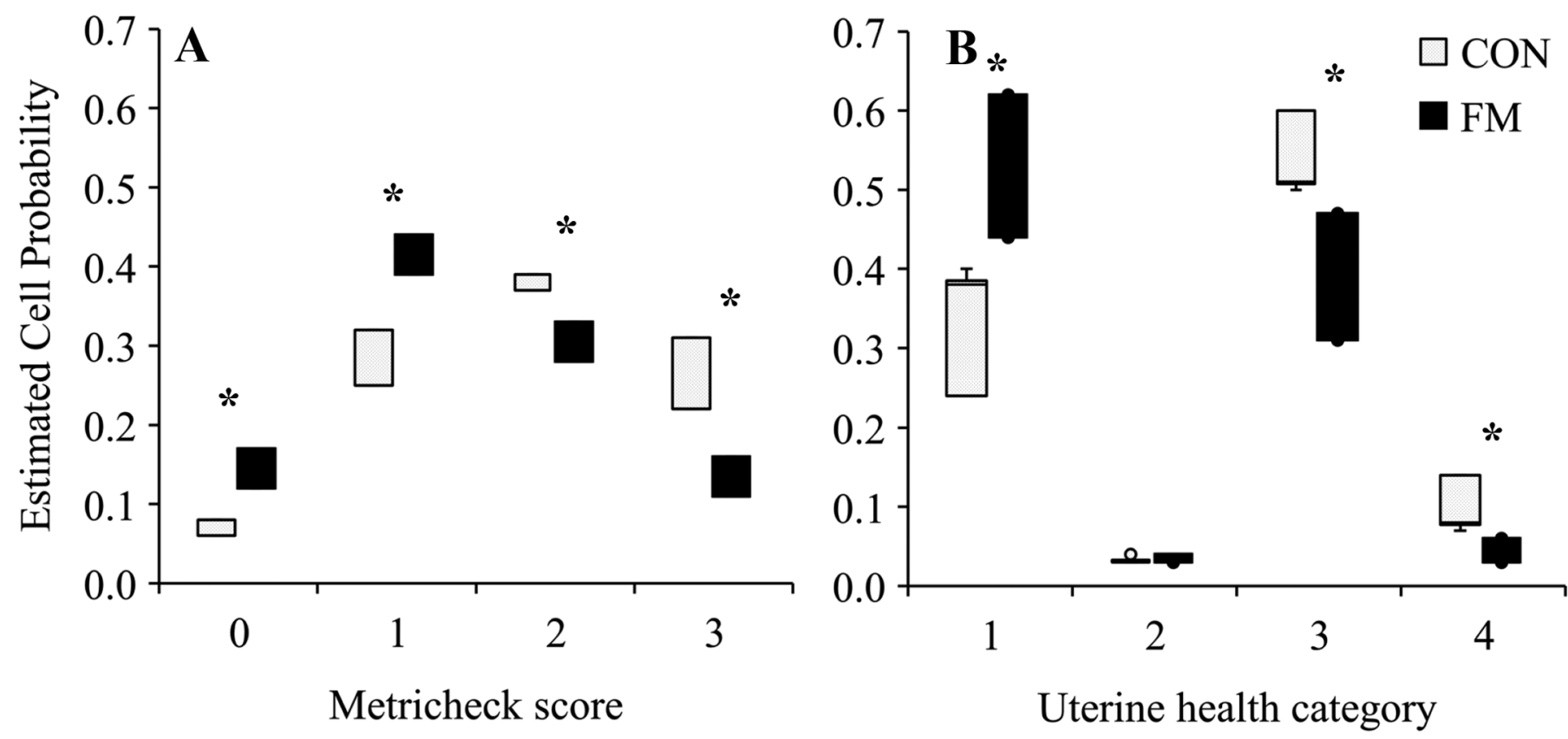

Figure 4. Boxplots showing estimated cell probability values derived from an ordinal regression model assessing the effect of flunixin meglumine $(\mathrm{FM})$ treatment $[\mathrm{n}=75$ vs. a control group $(\mathrm{CON}): \mathrm{n}=78]$ in primiparous cows on $\mathrm{d} 15$ postpartum on the Metricheck $(\mathrm{MC})$ score $(\mathrm{A}$; score $0=$ clear, mucoid discharge; score $1=$ mucopurulent discharge with $<50 \%$ of pus; score $2=$ mucopurulent discharge with $>50 \%$ of pus; score 3 = brownish-reddish, watery, foul-smelling discharge) and uterine health category (B) based on MC score and rectal body temperature (RBT; category $1=\mathrm{MC}$ score $\leq 1$ and $\mathrm{RBT}<39.5^{\circ} \mathrm{C}$; category $2=\mathrm{MC}$ score $\leq 1$ and $\mathrm{RBT} \geq 39.5^{\circ} \mathrm{C}$; category $3=\mathrm{MC}$ score $\geq 2$ and $\mathrm{RBT}$ $<39.5^{\circ} \mathrm{C}$; category $4=\mathrm{MC}$ score $\geq 2$ and $\mathrm{RBT} \geq 39.5^{\circ} \mathrm{C}$ ), respectively. $*$ indicates a significant difference between treatment groups within a category (Mann-Whitney-U-Test). Overall treatment effect: $P=0.01$ (for A and B). Data are presented as estimated cell probability values (\%) for each category of MC score and uterine health category, respectively, derived from an ordinal regression model. Boxes do not show middle lines, because of the oblique data distribution. The median is located either at the upper or lower margin of the box. Due to the narrow range of this type of data, either small or no whiskers at all are displayed. 


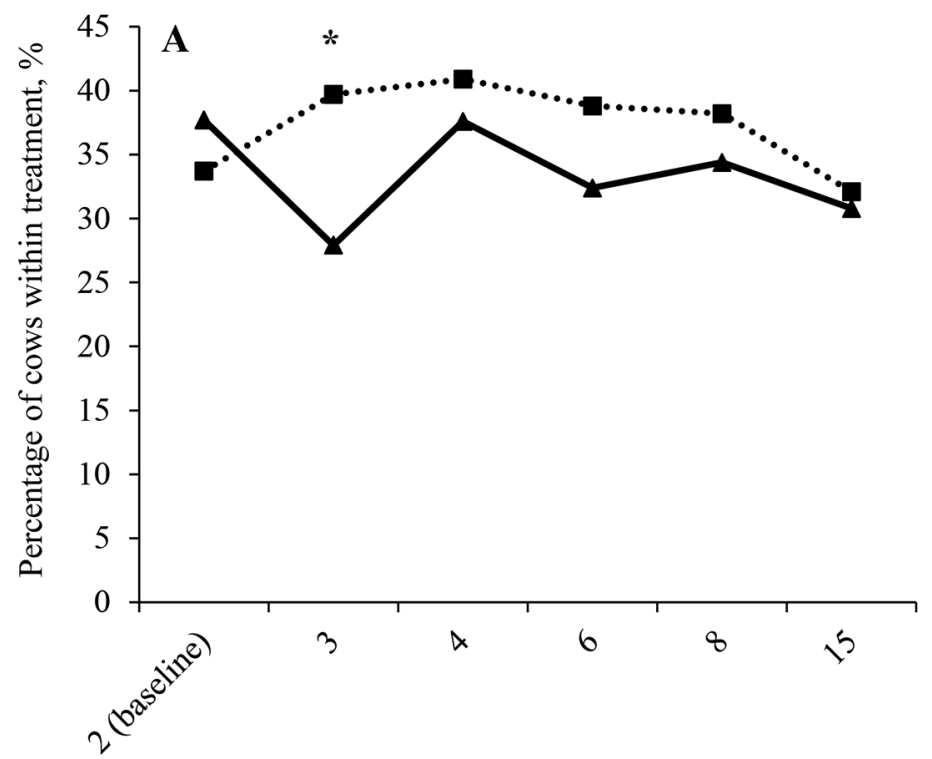

Days in milk

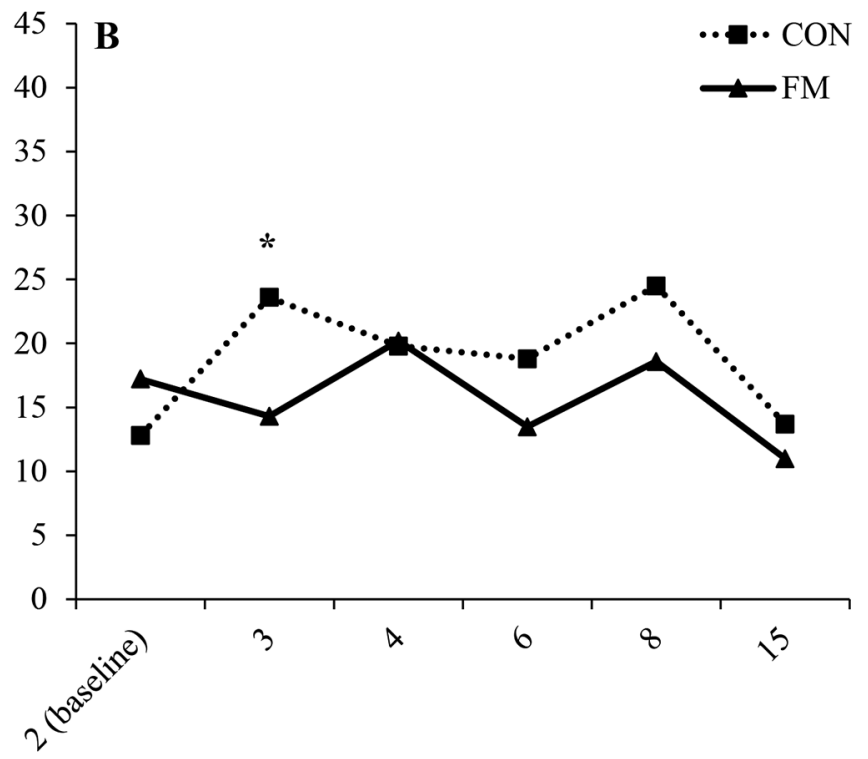

Days in milk

Figure 5. Raw percentages of cows within treatment that showed an arched back (A) or abducted the tail from their body (B). Treatment was performed on $\mathrm{d} 2$ postpartum and consisted of a placebo $(\mathrm{CON}, \mathrm{n}=250)$ and flunixin meglumine $(\mathrm{FM}, \mathrm{n}=250)$, respectively. ${ }^{*}$ represents a significant difference between treatment groups within a day (Chi-squared test; $P<0.05$ ).

2010). Dairy cows are known to begin mobilizing NEFA from adipose tissues already in the prepartum period, whereas ketone body formation usually does not exceed physiological ranges until after calving (LeBlanc, 2010). Therefore, although FM treatment might have positively influenced postpartum DMI and, hence, slightly reduced gluconeogenesis rate and ketone body formation, serum NEFA concentrations might not have been influenced by treatment.

In alignment with the aforementioned findings, primiparous cows treated with transdermal FM showed lower odds of having purulent vaginal discharge with or without a fever (defined as MC score 2 and 3, and $\mathrm{UHC}=3$ and 4 , respectively) compared with untreated CON cows in this study. Our findings coincide with those of Barragan et al. (2021), who assessed the effects of 2 oral doses of ASA, one within $12 \mathrm{~h}$ p.p. and another $24 \mathrm{~h}$ later, with a comparable study population. Contradictory to this, previous studies have reported a higher risk for ASA-treated cows to develop puerperal metritis (Bertoni et al., 2004, 2008). Farney et al. (2013b) observed an increased metritis risk only for multiparous cows in third or greater lactation treated with ASA, another study has linked an increased risk for puerperal metritis in FM-treated cows to the higher risk of RFM (Newby et al., 2017), as already discussed above. Mainau et al. (2014) and Swartz et al. (2018) reported no difference in metritis risk for MEL treated cows within the first $14 \mathrm{~d}$ p.p., and Richards et al.
(2009) found no difference in endometritis risk on d 21 p.p. between cows treated with KET and untreated controls. Possible reasons for discrepancies between studies and differences between parities have already been outlined above.

Finally, cows treated with FM were less likely to abduct their tail from their body or show an arched back on d 3 p.p., representing the day after treatment. Abnormal tail positioning and back arching are typical symptoms of abdominal pain in cattle (Millman, 2013; Braun et al., 2020; Yu et al., 2020). Nonsteroidal anti-inflammatory drugs have already proven efficient in reducing symptoms or decreasing biomarkers of pain after parturition in cattle (Newby et al., 2013b; Barragan et al., 2018a). Therefore, the reduced risk for treated cows to abduct their tail or show an arched back was most likely due to the anti-inflammatory action of FM, reducing the amount of circulating PG, hence alleviating some calving-associated pain and supporting the cow's general wellbeing. Interestingly, Stojkov et al. (2015) reported a significant correlation between back arching and metritis, which might have also been associated in the present study.

It should be mentioned that all significant differences between FM-treated cows and CON cows reported in this study were either small in their magnitude (e.g., RBT and HP in primiparous cows, BHB in multiparous cows) or only observed temporarily on the day after treatment (e.g., tail abduction, back arching). One 
possible reason might be the relatively short plasma half-life $(4-6 \mathrm{~h})$ of FM after a single administration. However, although the pharmacokinetics of multiple doses of transdermal FM have already been investigated (Kleinhenz et al., 2018), clinical efficacy, possible adverse effects, and an appropriate withdrawal time are still being assessed. For the single administration, a withdrawal period of $7 \mathrm{~d}$ for meat and $36 \mathrm{~h}$ for milk is declared. Finadyne Transdermal is approved for the treatment of bovine respiratory disease, acute mastitis, interdigital phlegmon, interdigital dermatitis, and digital dermatitis. In this study, an extra-label use was performed in early postpartum cows.

Finally, optimized cow comfort, diet, calving management, hygiene and body condition should still be considered the primary key to preventing excessive postpartum inflammation and solving herd health issues in the transition period. Especially heifers seem to be more susceptible to systemic inflammation around parturition, as indicated by increased APP concentrations (Humblet et al., 2006; Schneider et al., 2013; Mainau et al., 2014) and reduced DMI (Reshalaitihan et al., 2020). This might be attributable to a relatively high level of social stress at first calving (Chebel et al., 2016), a higher incidence of calving difficulties (Reshalaitihan and Hanada, 2019), and vulvo-vaginal lesions (Vieira-Neto et al., 2016). Dairy herd management should therefore focus on optimizing comfort for primiparous cows during the transition period. Based on the results of the present study, additional treatment of early postpartum cows, most specifically primiparous cows, with transdermal FM might be beneficial. Future research in this field should focus on comparing the effects of FM treatment using other timings and dosing regimens (e.g., multiple applications).

The quasi-random allocation (alternating treatment with FM and a placebo, respectively, within parities) performed in this study did result in a sufficient comparability of the treatment groups regarding cow-level covariates, such as time from calving to treatment, lactation number, body condition, and blood serum concentrations of different metabolites. However, the abovementioned randomization approach entails a greater risk of selection bias compared with other randomization techniques (e.g., the use of a randomization software). Therefore, internal validity of the present study is limited regarding those variables subjectively measured (scored) by the operator (i.e., MC score, BCS, LS, RF score, back arching, and tail abduction). Due to triple-blinding (patient, operator, and researchers performing statistical analysis), however, the other variables (RBT, laboratory parameters) could not have been impaired. Furthermore, animals requiring supportive therapy within the first 15 DIM were not excluded from the study. On the one hand, excluding these cows would have possibly confounded our results, as negative treatment effects would have been concealed. However, treatment with NSAID and AB most likely changed these cows' clinical and laboratory parameters, which could have interfered with our results. However, due to the small total number of cows requiring supportive therapy, and because this number was not different between treatment groups, we decided to include these animals in our analyses.

\section{CONCLUSIONS}

The single transdermal administration of FM between 24 to 36 h p.p. in Holstein Friesian dairy cows from farms with increased systemic inflammation postpartum slightly decreased RBT, reduced serum HP, and increased serum Alb concentration in primiparous cows. Serum BHB concentration was slightly lower in FM-treated multiparous cows compared with controls. Primiparous cows treated with FM were less likely to show purulent vaginal discharge with or without a fever. Regardless of parity, fewer cows within the FM group abducted their tail from their body or showed an arched back on the day after treatment compared with the CON group. Therefore, it can be concluded that the treatment alleviated pain regardless of parity, diminished systemic inflammation and improved uterine health in primiparous cows, and reduced ketone body formation in multiparous cows.

\section{ACKNOWLEDGMENTS}

This study was financially supported by Intervet Deutschland GmbH, Unterschleissheim, Germany. The authors thank J. Baeumer from the laboratory of the Ruminant and Swine Clinic of the Free University of Berlin and C. Weber from Laboklin GmbH (Bad Kissingen, Germany) for the tremendous support with the sample analyses. Cordial thanks go out to the staff of all participating dairy farms and their veterinarians for their trust in this project and their unconditional support. J. Swinkels is employed by the Global Ruminants Business Unit of MSD Animal Health, Boxmeer, the Netherlands, and C.-C. Gelfert is employed by Intervet GesmbH, MSD Animal Health, Vienna, Austria. MSD Animal Health distributes the product Finadyne Transdermal on the market. Intervet Deutschland GmbH, a member of MSD Animal Health, provided financial support for this study. All other authors are independent veterinarians and researchers and did not receive direct payment for their contribution in this project. 


\section{REFERENCES}

Barragan, A. A., S. Bas, L. M. Bauman, J. Lakritz, J. Velez, J. D. Rozo Gonzalez, G. M. Schuenemann, and R. J. van Saun. 2018a. Effects of oral administration of acetylsalicylic acid on physiological parameters and biomarkers of inflammation, pain and stress in organic dairy cows that experienced vulvar lesion at calving. J. Dairy Sci. 101:363.

Barragan, A. A., S. Bas, E. Hovingh, and L. Byler. 2021. Effects of postpartum acetylsalicylic acid on uterine diseases and reproductive performance in dairy cattle. JDS Commun. 2:67-72. https:// doi.org/10.3168/jdsc.2020-0047.

Barragan, A. A., L. M. Bauman, G. M. Schuenemann, J. Velez, J. Lakritz, J. F. Coetzee, J. D. R. Gonzalez, J. M. Piñeiro, B. Menichetti, and S. Bas. 2020a. Administration of acetylsalicylic acid after parturition in lactating dairy cows under certified organic management: Part II. Biomarkers of nociception, inflammation, and stress. J. Dairy Sci. 103:11713-11722. https://doi.org/10 $.3168 / j d s .2020-18389$.

Barragan, A. A., E. Hovingh, S. Bas, J. Lakritz, L. Byler, A. Ludwikowski, S. Takitch, J. Zug, and S. Hann. 2020b. Effects of postpartum acetylsalicylic acid on metabolic status, health, and production in lactating dairy cattle. J. Dairy Sci. 103:8443-8452. https://doi.org/10.3168/jds.2019-17966.

Barragan, A. A., J. M. Piñeiro, G. M. Schuenemann, P. J. RajalaSchultz, D. E. Sanders, J. Lakritz, and S. Bas. 2018b. Assessment of daily activity patterns and biomarkers of pain, inflammation, and stress in lactating dairy cows diagnosed with clinical metritis. J. Dairy Sci. 101:8248-8258. https://doi.org/10.3168/jds.2018 -14510 .

Baumann, H., and J. Gauldie. 1994. The acute phase response. Immunol. Today 15:74-80. https://doi.org/10.1016/0167-5699(94)90137 $-6$.

Beretta, C., G. Garavaglia, and M. Cavalli. 2005. COX-1 and COX-2 inhibition in horse blood by phenylbutazone, flunixin, carprofen and meloxicam: An in vitro analysis. Pharmacol. Res. 52:302-306. https://doi.org/10.1016/j.phrs.2005.04.004.

Bertoni, G., E. Trevisi, X. Han, and M. Bionaz. 2008. Effects of inflammatory conditions on liver activity in puerperium period and consequences for performance in dairy cows. J. Dairy Sci. 91:33003310. https://doi.org/10.3168/jds.2008-0995.

Bertoni, G., E. Trevisi, and F. Piccioli-Cappelli. 2004. Effects of acetyl-salicylate used in post-calving of dairy cows. Vet. Res. Commun. 28:217-219. https://doi.org/10.1023/B:VERC.0000045410 .86004 .03 .

Bionaz, M., E. Trevisi, L. Calamari, F. Librandi, A. Ferrari, and G. Bertoni. 2007. Plasma paraoxonase, health, inflammatory conditions, and liver function in transition dairy cows. J. Dairy Sci. 90:1740-1750. https://doi.org/10.3168/jds.2006-445.

Bossaert, P., E. Trevisi, G. Opsomer, G. Bertoni, S. de Vliegher, and J. L. Leroy. 2012. The association between indicators of inflammation and liver variables during the transition period in highyielding dairy cows: An observational study. Vet. J. 192:222-225. https://doi.org/10.1016/j.tvjl.2011.06.004.

Bradford, B. J., and T. H. Swartz. 2020. Review: Following the smoke signals: Inflammatory signaling in metabolic homeostasis and homeorhesis in dairy cattle. Animal 14(S1):s144-s154. https://doi .org/10.1017/S1751731119003203.

Bradford, B. J., K. Yuan, J. K. Farney, L. K. Mamedova, and A. J. Carpenter. 2015. Invited review: Inflammation during the transition to lactation: New adventures with an old flame. J. Dairy Sci. 98:6631-6650. https://doi.org/10.3168/jds.2015-9683.

Braun, U., K. Nuss, S. Warislohner, C. Reif, C. Oschlies, and C. Gerspach. 2020. Diagnostic reliability of clinical signs in cows with traumatic reticuloperitonitis and abomasal ulcers. BMC Vet. Res. 16:359. https://doi.org/10.1186/s12917-020-02515-z.

Brodzki, P., K. Kostro, A. Brodzki, W. Wawron, J. Marczuk, and L. Kurek. 2015. Inflammatory cytokines and acute-phase proteins concentrations in the peripheral blood and uterus of cows that developed endometritis during early postpartum. Theriogenology 84:11-18. https://doi.org/10.1016/j.theriogenology.2015.02.006.
Burfeind, O., V. S. Suthar, R. Voigtsberger, S. Bonk, and W. Heuwieser. 2014. Body temperature in early postpartum dairy cows. Theriogenology 82:121-131. https://doi.org/10.1016/j.theriogenology .2014.03.006.

Carpenter, A. J., C. M. Ylioja, C. F. Vargas, L. K. Mamedova, L. G. Mendonca, J. F. Coetzee, L. C. Hollis, R. Gehring, and B. J. Bradford. 2016. Hot topic: Early postpartum treatment of commercial dairy cows with nonsteroidal antiinflammatory drugs increases whole-lactation milk yield. J. Dairy Sci. 99:672-679. https://doi .org/10.3168/jds.2015-10048.

Chan, J. P., C. C. Chang, W. L. Hsu, W. B. Liu, and T. H. Chen. 2010. Association of increased serum acute-phase protein concentrations with reproductive performance in dairy cows with postpartum metritis. Vet. Clin. Pathol. 39:72-78. https://doi.org/10 .1111/j.1939-165X.2009.00182.x.

Chebel, R. C., P. R. B. Silva, M. I. Endres, M. A. Ballou, and K. L. Luchterhand. 2016. Social stressors and their effects on immunity and health of periparturient dairy cows. J. Dairy Sci. 99:32173228. https://doi.org/10.3168/jds.2015-10369.

Dohoo, I. R., S. W. Martin, and H. Stryhn. 2009. Veterinary Epidemiologic Research. Vol. 2. University of Prince Edward Island.

Edmonson, A. J., I. J. Lean, L. D. Weaver, T. Farver, and G. Webster. 1989. A body condition scoring chart for Holstein dairy cows. J. Dairy Sci. 72:68-78. https://doi.org/10.3168/jds.S0022 -0302(89)79081-0.

Ek, M., C. Arias, P. Sawchenko, and A. Ericsson-Dahlstrand. 2000. Distribution of the EP3 prostaglandin E2 receptor subtype in the rat brain: Relationship to sites of interleukin-1-induced cellular responsiveness. J. Comp. Neurol. 428:5-20. https://doi.org/10.1002/ 1096-9861(20001204)428:1<5::AID-CNE2>3.0.CO;2-M.

El-Deeb, W. M., and S. M. El-Bahr. 2017. Biomarkers of ketosis in dairy cows at postparturient period: Acute phase proteins and proinflammatory cytokines. Vet. Arh. 87:431-440. https://doi.org/10 $.24099 /$ vet.arhiv.160126c.

Farney, J. K., L. K. Mamedova, J. F. Coetzee, B. KuKanich, L. M. Sordillo, S. K. Stoakes, J. E. Minton, L. C. Hollis, and B. J. Bradford. 2013a. Anti-inflammatory salicylate treatment alters the metabolic adaptations to lactation in dairy cattle. Am. J. Physiol. Regul. Integr. Comp. Physiol. 305:R110-R117. https://doi.org/10 .1152 /ajpregu.00152.2013.

Farney, J. K., L. K. Mamedova, J. F. Coetzee, J. E. Minton, L. C. Hollis, and B. J. Bradford. 2013b. Sodium salicylate treatment in early lactation increases whole-lactation milk and milk fat yield in mature dairy cows. J. Dairy Sci. 96:7709-7718. https://doi.org/10 $.3168 /$ jds.2013-7088.

Giammarco, M., I. Fusaro, G. Vignola, A. C. Manetta, A. Gramenzi, M. Fustini, A. Palmonari, and A. Formigoni. 2018. Effects of a single injection of Flunixin meglumine or Carprofen postpartum on haematological parameters, productive performance and fertility of dairy cattle. Anim. Prod. Sci. 58:322-331. https://doi.org/ 10.1071/AN16028.

Giannetto, C., F. Fazio, S. Casella, S. Marafioti, E. Giudice, and G. Piccione. 2011. Acute phase protein response during road transportation and lairage at a slaughterhouse in feedlot beef cattle. J. Vet. Med. Sci. 73:1531-1534. https://doi.org/10.1292/jvms.11 -0157 .

Gladden, N., D. McKeegan, L. Viora, and K. A. Ellis. 2018. Postpartum ketoprofen treatment does not alter stress biomarkers in cows and calves experiencing assisted and unassisted parturition: A randomised controlled trial. Vet. Rec. 183:414. https://doi.org/ $10.1136 / v r .104913$.

Guzelbektes, H., I. Sen, M. Ok, P. D. Constable, M. Boydak, and A. Coskun. 2010. Serum amyloid A and haptoglobin concentrations and liver fat percentage in lactating dairy cows with abomasal displacement. J. Vet. Intern. Med. 24:213-219. https://doi.org/10 $.1111 / \mathrm{j} .1939-1676.2009 .0444 . x$.

Heinrich, P. C., J. V. Castell, and T. Andus. 1990. Interleukin-6 and the acute phase response. Biochem. J. 265:621-636. https://doi .org/10.1042/bj2650621.

Hinson, R. M., J. A. Williams, and E. Shacter. 1996. Elevated interleukin 6 is induced by prostaglandin $\mathrm{E}_{2}$ in a murine model of 
inflammation: Possible role of cyclooxygenase-2. Proc. Natl. Acad. Sci. USA 93:4885-4890. https://doi.org/10.1073/pnas.93.10.4885.

Humblet, M.-F., H. Guyot, B. Boudry, F. Mbayahi, C. Hanzen, F. Rollin, and J.-M. Godeau. 2006. Relationship between haptoglobin, serum amyloid A, and clinical status in a survey of dairy herds during a 6-month period. Vet. Clin. Pathol. 35:188-193. https:// doi.org/10.1111/j.1939-165X.2006.tb00112.x.

Huzzey, J. M., T. F. Duffield, S. J. Leblanc, D. M. Veira, D. M. Weary, and M. A. von Keyserlingk. 2009. Short communication: Haptoglobin as an early indicator of metritis. J. Dairy Sci. 92:621-625. https://doi.org/10.3168/jds.2008-1526.

Huzzey, J. M., S. Mann, D. V. Nydam, R. J. Grant, and T. R. Overton. 2015. Associations of peripartum markers of stress and inflammation with milk yield and reproductive performance in Holstein dairy cows. Prev. Vet. Med. 120:291-297. https://doi.org/10.1016/ j.prevetmed.2015.04.011.

Kelton, D. F., K. D. Lissemore, and R. E. Martin. 1998. Recommendations for recording and calculating the incidence of selected clinical diseases of dairy cattle. J. Dairy Sci. 81:2502-2509. https://doi .org/10.3168/jds.S0022-0302(98)70142-0.

Kleinhenz, M. D. 2018. Pharmacokinetic properties of transdermal flunixin in cattle and its use in pain models. $\mathrm{PhD}$ diss. Department of Anatomy and Physiology, Kansas State University.

Kleinhenz, M. D., P. J. Gorden, J. S. Smith, J. A. Schleining, K. E. Kleinhenz, L. L. Wulf, P. K. Sidhu, D. Rea, and J. F. Coetzee. 2018. Pharmacokinetics of multiple doses of transdermal flunixin meglumine in adult Holstein dairy cows. J. Vet. Pharmacol. Ther. 41:490-493. https://doi.org/10.1111/jvp.12490.

Kleinhenz, M. D., N. K. van Engen, P. J. Gorden, B. KuKanich, S. M. Rajewski, P. Walsh, and J. F. Coetzee. 2016. The pharmacokinetics of transdermal flunixin meglumine in Holstein calves. J. Vet. Pharmacol. Ther. 39:612-615. https://doi.org/10.1111/jvp.12314.

Königsson, K., K. Odensvik, and H. Kindahl. 2002. Endocrine, metabolic and clinical effects of intravenous endotoxin injection after pre-treatment with meloxicam in heifers. J. Vet. Med. A Physiol. Pathol. Clin. Med. 49:408-414. https://doi.org/10.1046/j.1439 $-0442.2002 .00461 . x$.

Kopp, E., and S. Ghosh. 1994. Inhibition of NF- $\kappa$ B by sodium salicylate and aspirin. Science 265:956-959. https://doi.org/10.1126/ science. 8052854

Kovacevic, Z., D. Stojanovic, M. Cincovic, B. Belic, I. Davidov, N. Plavsa, and M. Radinovic. 2018. Association of metabolic and inflammatory markers with milk yield in postpartum dairy cows treated with ketoprofen. Pol. J. Vet. Sci. 21:325-331. https://doi .org/10.24425/122600.

Krause, A. R. T., L. F. M. Pfeifer, P. Montagner, M. M. Weschenfelder, E. Schwegler, M. E. Lima, E. G. Xavier, C. C. Brauner, E. Schmitt, F. A. Del Pino, C. F. Martins, M. N. Corrêa, and A. Schneider. 2014. Associations between resumption of postpartum ovarian activity, uterine health and concentrations of metabolites and acute phase proteins during the transition period in Holstein cows. Anim. Reprod. Sci. 145:8-14. https://doi.org/10.1016/j .anireprosci.2013.12.016.

Lambertz, C., D. Völker, U. Janowitz, and M. Gauly. 2014. Evaluation of vaginal discharge with the Metricheck device and the relationship to reproductive performance in postpartum dairy cows. Anim. Sci. J. 85:848-852. https://doi.org/10.1111/asj.12219.

LeBlanc, S. 2010. Monitoring metabolic health of dairy cattle in the transition period. J. Reprod. Dev. 56(Suppl):S29-S35. https://doi .org/10.1262/jrd.1056S29.

Mainau, E., A. Cuevas, J. L. Ruiz-de-la-Torre, E. Abbeloos, and X. Manteca. 2014. Effect of meloxicam administration after calving on milk production, acute phase proteins, and behavior in dairy cows. J. Vet. Behav. 9:357-363. https://doi.org/10.1016/j.jveb 2014.07.007.

Makimura, S., and H. Suzuki. 1982. Quantitative determination of bovine serum haptoglobin and its elevation in some inflammatory diseases. Nippon Juigaku Zasshi 44:15-21. https://doi.org/10 $.1292 /$ jvms1939.44.15.

Martinez, M., and S. Modric. 2010. Patient variation in veterinary medicine: Part I. Influence of altered physiological states. J. Vet.
Pharmacol. Ther. 33:213-226. https://doi.org/10.1111/j.1365 $-2885.2009 .01139 . \mathrm{x}$

McCarthy, M. M., S. Mann, D. V. Nydam, T. R. Overton, and J. A. A. McArt. 2015. Short communication: Concentrations of nonesterified fatty acids and beta-hydroxybutyrate in dairy cows are not well correlated during the transition period. J. Dairy Sci. 98:62846290. https://doi.org/10.3168/jds.2015-9446.

McDougall, S., R. Macaulay, and C. Compton. 2007. Association between endometritis diagnosis using a novel intravaginal device and reproductive performance in dairy cattle. Anim. Reprod. Sci. 99:923. https://doi.org/10.1016/j.anireprosci.2006.03.017.

Meier, S., N. V. Priest, C. R. Burke, J. K. Kay, S. McDougall, M. D. Mitchell, C. G. Walker, A. Heiser, J. J. Loor, and J. R. Roche. 2014. Treatment with a nonsteroidal antiinflammatory drug after calving did not improve milk production, health, or reproduction parameters in pasture-grazed dairy cows. J. Dairy Sci. 97:29322943. https://doi.org/10.3168/jds.2013-7838.

Millman, S. T. 2013. Behavioral responses of cattle to pain and implications for diagnosis, management, and animal welfare. Vet. Clin North Am. Food Anim. Pract. 29:47-58. https://doi.org/10.1016/ j.cvfa.2012.11.007.

Montgomery, S. R., L. K. Mamedova, M. Zachut, G. Kra, S. Häussler, M. Vaughn, J. Gonzalez, and B. J. Bradford. 2019. Effects of sodium salicylate on glucose kinetics and insulin signaling in postpartum dairy cows. J. Dairy Sci. 102:1617-1629. https://doi.org/ $10.3168 /$ jds.2018-15312.

Newby, N. C., K. E. Leslie, H. D. P. Dingwell, D. F. Kelton, D. M. Weary, L. Neuder, S. T. Millman, and T. F. Duffield. 2017. The effects of periparturient administration of flunixin meglumine on the health and production of dairy cattle. J. Dairy Sci. 100:582-587. https://doi.org/10.3168/jds.2016-11747.

Newby, N. C., D. L. Pearl, S. J. Leblanc, K. E. Leslie, M. A. von Keyserlingk, and T. F. Duffield. 2013a. Effects of meloxicam on milk production, behavior, and feed intake in dairy cows following assisted calving. J. Dairy Sci. 96:3682-3688. https://doi.org/ $10.3168 /$ jds.2012-6214.

Newby, N. C., D. L. Pearl, S. J. Leblanc, K. E. Leslie, M. A. von Keyserlingk, and T. F. Duffield. 2013b. The effect of administering ketoprofen on the physiology and behavior of dairy cows following surgery to correct a left displaced abomasum. J. Dairy Sci. 96:1511-1520. https://doi.org/10.3168/jds.2012-5566.

Nightingale, C. R., M. D. Sellers, and M. A. Ballou. 2015. Elevated plasma haptoglobin concentrations following parturition are associated with elevated leukocyte responses and decreased subsequent reproductive efficiency in multiparous Holstein dairy cows. Vet. Immunol. Immunopathol. 164:16-23. https://doi.org/10.1016/J vetimm.2014.12.016.

Ospina, P. A., J. A. McArt, T. R. Overton, T. Stokol, and D. V. Nydam. 2013. Using nonesterified fatty acids and beta-hydroxybutyrate concentrations during the transition period for herd-level monitoring of increased risk of disease and decreased reproductive and milking performance. Vet. Clin. North Am. Food Anim. Pract. 29:387-412. https://doi.org/10.1016/j.cvfa.2013.04.003.

Owen, J. A., F. C. Better, and J. Hoban. 1960. A simple method for the determination of serum haptoglobins. J. Clin. Pathol. 13:163164. https://doi.org/10.1136/jcp.13.2.163.

Pascottini, O. B., M. R. Carvalho, S. J. van Schyndel, E. Ticiani, J. W. Spricigo, L. K. Mamedova, E. S. Ribeiro, and S. J. LeBlanc. 2019. Feed restriction to induce and meloxicam to mitigate potential systemic inflammation in dairy cows before calving. J. Dairy Sci. 102:9285-9297. https://doi.org/10.3168/jds.2019-16558.

Pascottini, O. B., S. J. van Schyndel, J. F. W. Spricigo, M. R. Carvalho, B. Mion, E. S. Ribeiro, and S. J. Leblanc. 2020. Effect of anti-inflammatory treatment on systemic inflammation, immune function, and endometrial health in postpartum dairy cows. Sci. Rep. 10:5236. https://doi.org/10.1038/s41598-020-62103-x.

Pohl, A., O. Burfeind, and W. Heuwieser. 2015. The associations between postpartum serum haptoglobin concentration and metabolic status, calving difficulties, retained fetal membranes, and metritis. J. Dairy Sci. 98:4544-4551. https://doi.org/10.3168/jds.2014-9181. 
Reshalaitihan, M., and M. Hanada. 2019. Influence of calving difficulty on dry matter intake immediately after calving of dairy cows. Anim. Sci. J. 90:539-546. https://doi.org/10.1111/asj.13188.

Reshalaitihan, M., S. Wynn, M. Teramura, T. Sato, and M. Hanada. 2020. Effect of parity number on the dry matter intake of dairy cows during the first week after calving. Anim. Sci. J. 91:e13314. https://doi.org/10.1111/asj.13314.

Richards, B. D., D. H. Black, R. M. Christley, M. D. Royal, R. F. Smith, and H. Dobson. 2009. Effects of the administration of ketoprofen at parturition on the milk yield and fertility of HolsteinFriesian cattle. Vet. Rec. 165:102-106. https://doi.org/10.1136/ vetrec.165.4.102.

Schmitt, R., L. Pieper, S. Borchardt, J. M. Swinkels, C. C. Gelfert, and R. Staufenbiel. 2021a. Effects of a single transdermal administration of flunixin meglumine in early postpartum Holstein Friesian dairy cows: Part 1 . Inflammatory and metabolic markers, uterine health, and indicators of pain. Supplementary file. Zenodo. https: //doi.org/10.5281/zenodo.5595243.

Schmitt, R., L. Pieper, L. A. Gonzalez-Grajales, J. Swinkels, C.-C. Gelfert, and R. Staufenbiel. 2021b. Evaluation of different acutephase proteins for herd health diagnostics in early postpartum Holstein Friesian dairy cows. J. Dairy Res. 88:33-37. https://doi .org/10.1017/S0022029921000078.

Schneider, A., M. N. Corrêa, and W. R. Butler. 2013. Short communication: Acute phase proteins in Holstein cows diagnosed with uterine infection. Res. Vet. Sci. 95:269-271. https://doi.org/10.1016/j .rvsc.2013.02.010.

Schuenemann, G. M., I. Nieto, S. Bas, K. N. Galvão, and J. Workman. 2011. Assessment of calving progress and reference times for obstetric intervention during dystocia in Holstein dairy cows. J. Dairy Sci. 94:5494-5501. https://doi.org/10.3168/jds.2011-4436.

Senosy, W., M. Uchiza, N. Tameoka, Y. Izaike, and T. Osawa. 2012. Evaluation of reproductive tract infection during early post-partum period and its relationship with subsequent reproductive performance in high milk producing dairy cows. Reprod. Domest. Anim. 47:203-207. https://doi.org/10.1111/j.1439-0531.2011 $.01829 . x$.

Sheldon, I. M., J. G. Cronin, and J. J. Bromfield. 2019. Tolerance and innate immunity shape the development of postpartum uterine disease and the impact of endometritis in dairy cattle. Annu. Rev. Anim. Biosci. 7:361-384. https://doi.org/10.1146/annurev-animal -020518-115227.

Sheldon, I. M., and H. Dobson. 2004. Postpartum uterine health in cattle. Anim. Reprod. Sci. 82-83:295-306. https://doi.org/10 .1016/j.anireprosci.2004.04.006.

Sheldon, I. M., G. S. Lewis, S. LeBlanc, and R. O. Gilbert. 2006. Defining postpartum uterine disease in cattle. Theriogenology 65:1516-1530. https://doi.org/10.1016/j.theriogenology.2005.08 .021 .

Shwartz, G., K. L. Hill, M. J. VanBaale, and L. H. Baumgard. 2009. Effects of flunixin meglumine on pyrexia and bioenergetic variables in postparturient dairy cows. J. Dairy Sci. 92:1963-1970. https://doi.org/10.3168/jds.2008-1581.

Sordillo, L. M., G. A. Contreras, and S. L. Aitken. 2009. Metabolic factors affecting the inflammatory response of periparturient dairy cows. Anim. Health Res. Rev. 10:53-63. https://doi.org/10.1017/ S1466252309990016.

Sordillo, L. M., and W. Raphael. 2013. Significance of metabolic stress, lipid mobilization, and inflammation on transition cow disorders. Vet. Clin. North Am. Food Anim. Pract. 29:267-278. https://doi .org/10.1016/j.cvfa.2013.03.002.

Sprecher, D. J., D. E. Hostetler, and J. B. Kaneene. 1997. A lameness scoring system that uses posture and gait to predict dairy cattle reproductive performance. Theriogenology 47:1179-1187. https:// doi.org/10.1016/S0093-691X(97)00098-8.

Stojkov, J., M. A. G. von Keyserlingk, J. N. Marchant-Forde, and D. M. Weary. 2015. Assessment of visceral pain associated with me- tritis in dairy cows. J. Dairy Sci. 98:5352-5361. https://doi.org/10 $.3168 /$ jds.2014-9296.

Suthar, V., O. Burfeind, S. Bonk, R. Voigtsberger, C. Keane, and W. Heuwieser. 2012. Factors associated with body temperature of healthy Holstein dairy cows during the first 10 days in milk. J. Dairy Res. 79:135-142. https://doi.org/10.1017/S0022029911000896.

Swartz, T. H., H. H. Schramm, J. M. Bewley, C. M. Wood, K. E. Leslie, and C. S. Petersson-Wolfe. 2018. Meloxicam administration either prior to or after parturition: Effects on behavior, health, and production in dairy cows. J. Dairy Sci. 101:10151-10167. https:// doi.org/10.3168/jds.2018-14657.

Thesing, E., C. Ströbel, J. Beisel, D. Lange, and C.-C. Gelfert. 2016. Früher Einsatz von NSAID bei Atemwegserkrankungen - eine Anwendungsbeobachtung auf zwei Rindermastbetrieben. Tierarztl. Umsch. 71:346-352.

Thiry, J., R. Fournier, O. Roy, and M. Catala. 2017. Evaluation of flunixin meglumine pour-on administration on prostaglandin E2 concentration in inflammatory exudate after induction of inflammation in cattle. Res. Vet. Sci. 114:294-296. https://doi.org/10 $.1016 /$ j.rvsc. 2017.04.010.

Trevisi, E., M. Amadori, I. Archetti, N. Lacetera, and G. Bertoni. 2011. Inflammatory response and acute phase proteins in the transition period of high-yielding dairy cows. Chapter 14, pages 355-373 in Acute Phase Proteins as Early Non-Specific Biomarkers of Human and Veterinary Diseases. F. Veas, ed. InTech. https: //doi.org/10.5772/20747.

Venjakob, P. L., R. Staufenbiel, W. Heuwieser, and S. Borchardt. 2019. Serum calcium dynamics within the first 3 days in milk and the associated risk of acute puerperal metritis. J. Dairy Sci. 102:1142811438. https://doi.org/10.3168/jds.2019-16721.

Vieira-Neto, A., F. S. Lima, J. E. P. Santos, R. D. Mingoti, G. S. Vasconcellos, C. A. Risco, and K. N. Galvao. 2016. Vulvovaginal laceration as a risk factor for uterine disease in postpartum dairy cows. J. Dairy Sci. 99:4629-4637. https://doi.org/10.3168/jds.2016 -10872 .

Waelchli, R. O., R. Thun, and H. Stocker. 1999. Effect of flunixin meglumine on placental expulsion in dairy cattle after a cesarean. Vet. Rec. 144:702-703. https://doi.org/10.1136/vr.144.25.702.

Wenz, J. R., D. A. Moore, and R. Kasimanickam. 2011. Factors associated with the rectal temperature of Holstein dairy cows during the first 10 days in milk. J. Dairy Sci. 94:1864-1872. https://doi.org/ $10.3168 /$ jds.2010-3924

Yu, A., D. van der Saag, P. Letchford, P. Windsor, and P. White. 2020. Preliminary investigation to address pain and haemorrhage following the spaying of female cattle. Animals (Basel) 10:249. https:// doi.org/10.3390/ani10020249.

Yuan, M., N. Konstantopoulos, J. Lee, L. Hansen, Z.-W. Li, M. Karin, and S. E. Shoelson. 2001. Reversal of obesity- and diet-induced insulin resistance with salicylates or targeted disruption of Ikk $\beta$. Science 293:1673-1677. https://doi.org/10.1126/science.1061620.

Zaaijer, D., and J. P. T. M. Noordhuizen. 2003. A novel scoring system for monitoring the relationship between nutritional efficiency and fertility in dairy cows. Ir. Vet. J. 56:145-151.

\section{ORCIDS}

R. Schmitt ( https://orcid.org/0000-0002-2501-0497

L. Pieper @ https://orcid.org/0000-0002-3765-5401

S. Borchardt (1) https://orcid.org/0000-0003-3937-5777

J. M. Swinkels @ https://orcid.org/0000-0001-7267-8097

C.-C. Gelfert $\odot$ https://orcid.org/0000-0002-6471-5983

R. Staufenbiel $\odot$ https://orcid.org/0000-0001-7983-4603 